\title{
Evaporative evolution of a $\mathrm{Na}-\mathrm{Cl}-\mathrm{NO}_{3}-\mathrm{K}-\mathrm{Ca}-\mathrm{SO}_{4}-\mathrm{Mg}-\mathrm{Si}$ brine at $95{ }^{\circ} \mathrm{C}$ : Experiments and modeling relevant to Yucca Mountain, Nevada
}

\author{
Maureen Alai, ${ }^{a}$ ) Mark Sutton, and Susan Carroll \\ Lawrence Livermore National Laboratory, Livermore, California 94550
}

(Received 5 November 2004; accepted 21 April 2005; published 7 June 2005)

\begin{abstract}
A synthetic Topopah Spring Tuff water representative of one type of pore water at Yucca Mountain, $\mathrm{NV}$ was evaporated at $95^{\circ} \mathrm{C}$ in a series of experiments to determine the geochemical controls for brines that may form on, and possibly impact upon the long-term integrity of waste containers and drip shields at the designated high-level, nuclear-waste repository. Solution chemistry, condensed vapor chemistry, and precipitate mineralogy were used to identify important chemical divides and to validate geochemical calculations of evaporating water chemistry using a high temperature Pitzer thermodynamic database. The water evolved toward a complex "sulfate type" brine that contained about $45 \mathrm{~mol} \% \mathrm{Na}, 40 \mathrm{~mol} \% \mathrm{Cl}, 9 \mathrm{~mol} \% \mathrm{NO}_{3}, 5 \mathrm{~mol} \% \mathrm{~K}$, and less than $1 \mathrm{~mol} \%$ each of $\mathrm{SO}_{4}$, $\mathrm{Ca}, \mathrm{Mg}, \Sigma \mathrm{CO}_{2}(\mathrm{aq}), \mathrm{F}$, and $\mathrm{Si}$. All measured ions in the condensed vapor phase were below detection limits. The mineral precipitates identified were halite, anhydrite, bassanite, niter, and nitratine. Trends in the solution composition and identification of $\mathrm{CaSO}_{4}$ solids suggest that fluorite, carbonate, sulfate, and magnesium-silicate precipitation control the aqueous solution composition of sulfate type waters by removing fluoride, calcium, and magnesium during the early stages of evaporation. In most cases, the high temperature Pitzer database, used by EQ3/6 geochemical code, sufficiently predicts water composition and mineral precipitation during evaporation. Predicted solution compositions are generally within a factor of 2 of the experimental values. The model predicts that sepiolite, bassanite, amorphous silica, calcite, halite, and brucite are the solubility controlling mineral phases. (C) 2005 American Institute of Physics. [DOI: 10.1063/1.1935432]
\end{abstract}

\section{INTRODUCTION}

Yucca Mountain, NV, is the designated site for a permanent geologic repository for high-level nuclear waste in the USA. The current waste package design consists of a doublewalled container with an inner barrier of stainless steel, an outer barrier of highly corrosion resistant nickel-chromiummolybdenum alloy, and a titanium alloy drip-shield that covers the containers. Corrosion resistance and long-term integrity of the metal containers and shields are important for the safe disposal of the waste. Characterization of the compositional evolution of waters that affect waste package corrosion is necessary. If the site is licensed, the waste packages will be placed in tunnels several hundred meters below the ground surface and above the groundwater table in partially saturated volcanic tuff. Once the waste packages are in place, the repository will heat up due to the thermal energy of the nuclear waste. Although the waste packages will be above the groundwater table, pore water present in rock formations within (Topopah Spring Tuff) and above (Paintbrush Tuff) the repository may come into contact with the metal containers and shields. Additionally, brines may form from the deliquescence of salts found in dusts deposited on the containers. ${ }^{1}$ In this study we focus on seepage brines formed by the evaporation of pore water at elevated temperature.

One method of evaluating the evolution of a brine is the chemical divide theory, which has been used to describe saline lake geochemistry. ${ }^{2-5}$ The chemical divide theory gener-

\footnotetext{
${ }^{\text {a) }}$ Author to whom all correspondence should be addressed; electronic mail: alai1@1ln1.gov
}

ally describes the chemical evolution of dilute waters upon evaporation in terms of their equivalent calcium, sulfate, and bicarbonate ratios and is shown in Fig. 1(a). The chemical evolution of evaporating water is controlled by the high solubility of salt minerals relative to the moderate solubility of calcium sulfate and low solubility of calcium carbonate minerals. A bicarbonate alkaline brine $\left(\mathrm{Na}-\mathrm{K}-\mathrm{CO}_{3}-\mathrm{Cl}-\mathrm{SO}_{4}-\mathrm{NO}_{3}\right)$ forms from dilute waters with dissolved calcium concentrations that are less than dissolved carbonate $\left(\mathrm{Ca}<\mathrm{HCO}_{3}+\mathrm{CO}_{3}\right.$, equivalent $\left.\%\right)$. A sulfate brine with near neutral $p \mathrm{H}\left(\mathrm{Na}-\mathrm{K}-\mathrm{Mg}-\mathrm{Cl}-\mathbf{S O}_{4}-\mathrm{NO}_{3}\right)$ forms from dilute waters with dissolved calcium concentrations that are greater than the dissolved carbonate, but less than the combined dissolved sulfate and carbonate concentrations $\left(\mathrm{Ca}<\mathrm{SO}_{4}+\mathrm{HCO}_{3}\right.$, equivalent $\left.\%\right)$. A calcium chloride brine with near neutral $p \mathrm{H}\left(\mathrm{Na}-\mathrm{K}-\mathrm{Ca}-\mathrm{Mg}-\mathrm{Cl}-\mathrm{NO}_{3}\right)$ forms from dilute waters with a dissolved calcium concentration that is greater than the combined dissolved sulfate and carbonate concentrations $\left(\mathrm{Ca}>\mathrm{SO}_{4}+\mathrm{HCO}_{3}\right.$, equivalent\%). The measured compositions of Yucca Mountain pore water vary, but can be generally classified as waters that should evolve toward sulfate and sodium bicarbonate type brines, with a few calcium chloride brines as they evaporate [Fig. $1(\mathrm{~b})] .^{6-8}$

In Fig. 1, the simple ratios of calcium, sulfate, and carbonate illustrate the dominant carbonate and sulfate chemical divides that occur as waters evaporate. ${ }^{2,9,10}$ However, Fig. 1 does not show important chemical divides for magnesium, silica, or fluoride, nor does it show the relative amount of these salts to other major ions such as sodium, chloride, and 
A.

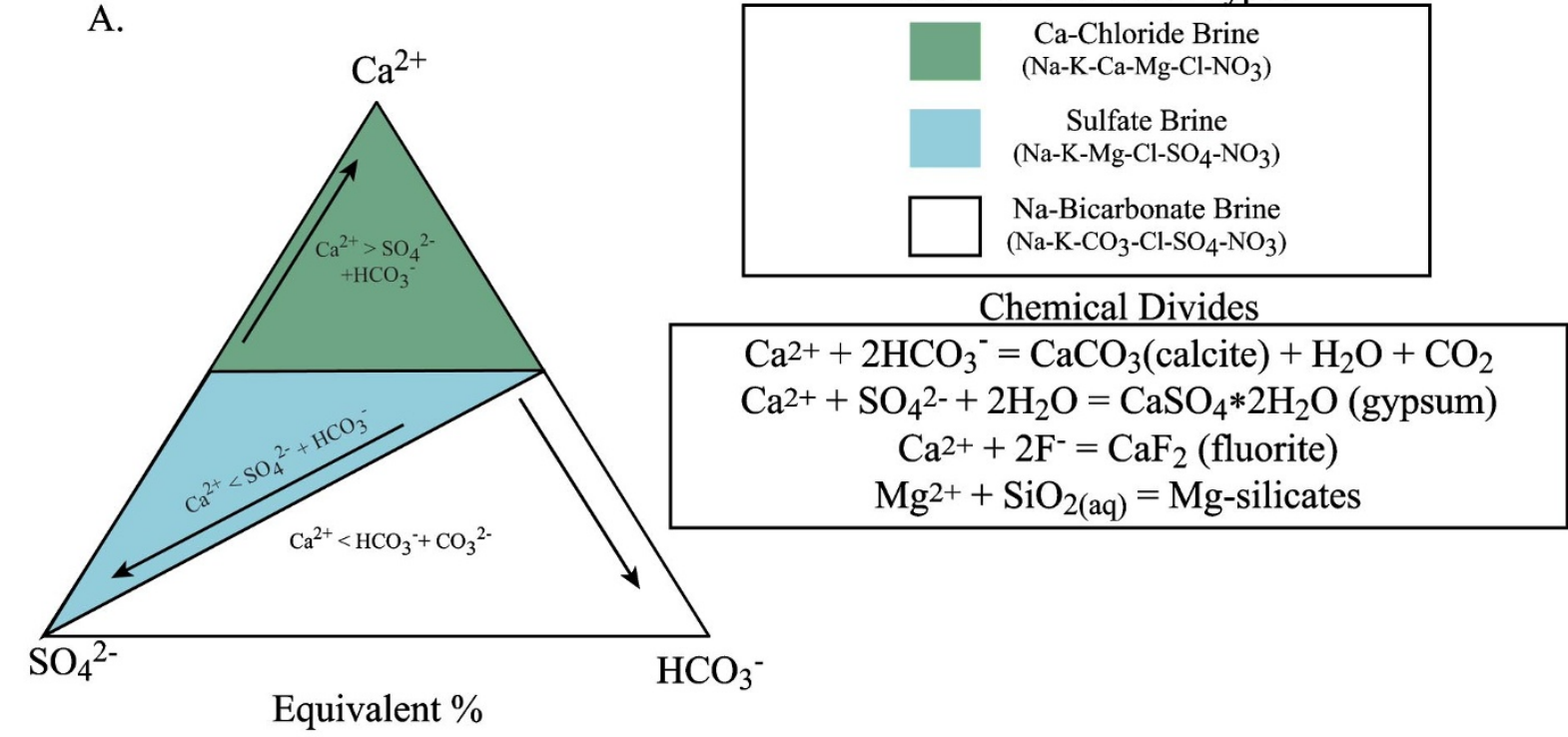

Possible Pore Water Types

\section{Ca-Chloride Brine}

a-K-Ca-Mg-Cl-NO 3 )

Sulfate Brine

a-K-Mg-Cl-SO $4-\mathrm{NO}_{3}$

Chemical Divides

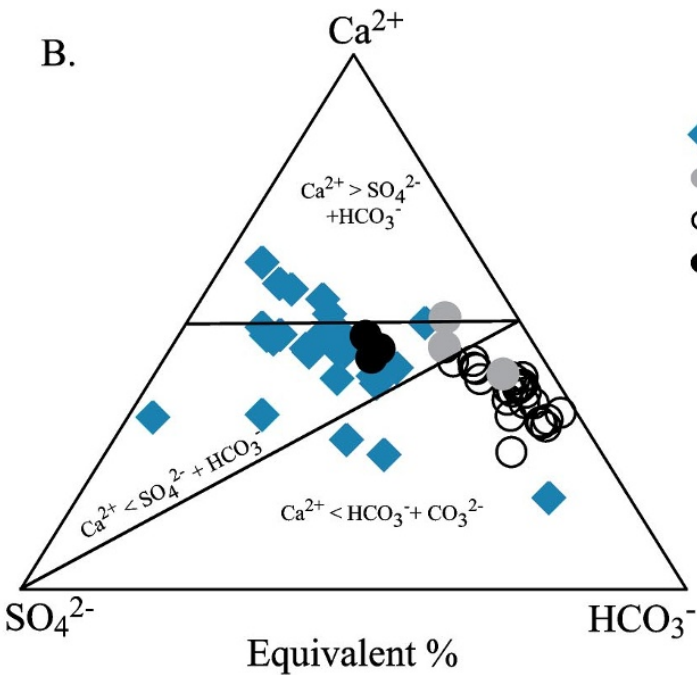

Paintbrush Tuff ${ }^{5}$

- Topopah Spring Tuff 5

- Topopah Spring Tuff ${ }^{6}$, Charge Balance on $\mathrm{HCO}_{3}{ }^{-}$

- Topopah Spring Tuff ${ }^{7}$, Charge Balance on $\mathrm{HCO}_{3}{ }^{-}$

Equivalent \%

FIG. 1. (Color) (a) Calcium carbonate and calcium sulfate chemical divides for evaporation of dilute waters. (b) Yucca Mountain, NV pore waters as measured.

nitrate. These are important chemical parameters, because they may mitigate or enhance the corrosiveness of brines at the waste package surfaces. Temperature will also impact the evolution of the pore water. Previous modeling of Yucca Mountain pore water initially within the sulfate brine field at $25{ }^{\circ} \mathrm{C}$ evolved toward calcium chloride brines at $95{ }^{\circ} \mathrm{C}$, and not toward a sulfate brine as predicted by Fig. 1(a). ${ }^{7}$

Thermodynamic equilibrium codes use a range of seepage water chemistry, temperature, and relative humidity to model the chemical environment on Yucca Mountain waste package surfaces. ${ }^{1}$ This requires Pitzer parameters that can account for nonideal solutions at higher ionic strengths and elevated temperatures. Unfortunately, only a few relevant experiments are available to validate this modeling approach. The available data consist of evaporation of two bicarbonate type waters modeled after Yucca Mountain J-13 well water and a calcium chloride type water modeled after unsaturated pore water at Yucca Mountain and seawater. ${ }^{1,5}$

In this paper we focus on the brine chemistry formed by the evaporation of a synthetic Yucca Mountain sulfate type pore water ${ }^{8}$ at $95{ }^{\circ} \mathrm{C}$ over a concentration range of $1 \times$ to $\sim 3500 \times$. This study provides additional benchmark data needed to both understand the brines and salts that form upon evaporation of various waters and to validate the EQ3/6 geochemical code and a high temperature Pitzer parameter thermodynamic database currently used by the Yucca Mountain Program to model aqueous chemical systems.

\section{METHODS}

\section{A. Experimental methods}

A synthetic pore water solution, based on HD-PERM-1 pore water composition, ${ }^{8}$ was evaporated about 3400 times at $95^{\circ} \mathrm{C}$ in a series of experiments to iteratively concentrate the solution in manageable quantities of approximately 21 and to monitor precipitation. The chemical composition of each successive leg was based on the brine composition toward the end of the previous leg (Table I). Experiments FEC 
TABLE I. Starting and final compositions for the evaporation of a synthetic "sulfate type" Topopah Spring Tuff pore water.

\begin{tabular}{|c|c|c|c|c|c|c|c|c|c|}
\hline & $\begin{array}{l}\text { Leg } 1 \\
\text { FEC } 9 \\
\text { molal }^{\text {a }} \\
\text { starting }^{\text {a }}\end{array}$ & $\begin{array}{c}\text { Leg } 1 \\
\text { FEC } 9 \\
\text { molal, } 95^{\circ} \mathrm{C} \\
\text { starting }\end{array}$ & $\begin{array}{c}\text { Leg } 1 \\
\text { FEC } 9 \\
\text { molal, } 95^{\circ} \mathrm{C} \\
\text { final }\end{array}$ & $\begin{array}{c}\text { Leg } 2 \\
\text { FEC } 12 \\
\text { molal, } 95^{\circ} \mathrm{C} \\
\text { starting }\end{array}$ & $\begin{array}{c}\text { Leg } 2 \\
\text { FEC } 12 \\
\text { molal, } 95^{\circ} \mathrm{C} \\
\text { final }\end{array}$ & $\begin{array}{c}\text { Leg } 3^{\mathrm{b}} \\
\text { FEC } 13 \\
\text { molal, } 95^{\circ} \mathrm{C} \\
\text { starting }\end{array}$ & $\begin{array}{c}\text { Leg } 3 \\
\text { FEC } 13 \\
\text { molal, } 95^{\circ} \mathrm{C} \\
\text { final }\end{array}$ & $\begin{array}{c}\text { Leg } 4^{\mathrm{b}} \\
\text { FEC } 14 \\
\text { molal, } 95^{\circ} \mathrm{C} \\
\text { starting }\end{array}$ & $\begin{array}{l}\text { Leg } 4 \\
\text { FEC } 14 \\
\text { molal, } 95^{\circ} \mathrm{C} \\
\quad \text { final }\end{array}$ \\
\hline $\mathrm{PH}^{\mathrm{a}}$ & 9.65 & $\mathrm{na}^{\mathrm{c}}$ & 7.15 & 7.60 & 7.32 & 7.69 & $\mathrm{na}^{\mathrm{c}}$ & 8.08 & 6.97 \\
\hline F & $5.94 \times 10^{-5}$ & $n d^{d}$ & $n d^{d}$ & $\mathrm{nd}^{\mathrm{d}}$ & $\mathrm{nd}^{\mathrm{d}}$ & $\mathrm{nd}^{\mathrm{d}}$ & $\mathrm{nd}^{\mathrm{d}}$ & $n d^{\mathrm{d}}$ & $\mathrm{nd}^{\mathrm{d}}$ \\
\hline $\mathrm{Ca}$ & $1.57 \times 10^{-3}$ & $1.25 \times 10^{-3}$ & $4.36 \times 10^{-3}$ & $4.69 \times 10^{-3}$ & $2.25 \times 10^{-2}$ & $2.17 \times 10^{-2}$ & $4.21 \times 10^{-2}$ & $4.06 \times 10^{-2}$ & $1.03 \times 10^{-2}$ \\
\hline $\mathrm{Mg}$ & $1.01 \times 10^{-3}$ & $6.48 \times 10^{-4}$ & $5.58 \times 10^{-4}$ & $6.05 \times 10^{-4}$ & $4.52 \times 10^{-3}$ & $1.06 \times 10^{-3}$ & $6.43 \times 10^{-3}$ & $1.88 \times 10^{-3}$ & $9.02 \times 10^{-3}$ \\
\hline $\mathrm{Na}$ & $2.84 \times 10^{-3}$ & $3.04 \times 10^{-3}$ & $9.23 \times 10^{-3}$ & $1.10 \times 10^{-2}$ & $1.05 \times 10^{-1}$ & $1.11 \times 10^{-1}$ & 1.15 & 1.12 & 7.42 \\
\hline $\mathrm{SiO}_{2}$ & $1.39 \times 10^{-3}$ & $9.21 \times 10^{-4}$ & $1.15 \times 10^{-3}$ & $1.38 \times 10^{-3}$ & $7.91 \times 10^{-3}$ & $2.24 \times 10^{-3}$ & $6.32 \times 10^{-3}$ & $3.09 \times 10^{-4}$ & $1.89 \times 10^{-5}$ \\
\hline $\mathrm{K}$ & $1.76 \times 10^{-4}$ & $1.63 \times 10^{-4}$ & $5.15 \times 10^{-4}$ & $5.82 \times 10^{-4}$ & $5.66 \times 10^{-3}$ & $6.54 \times 10^{-3}$ & $6.99 \times 10^{-2}$ & $7.89 \times 10^{-2}$ & $8.09 \times 10^{-1}$ \\
\hline $\mathrm{Cl}$ & $3.26 \times 10^{-3}$ & $3.31 \times 10^{-3}$ & $1.00 \times 10^{-2}$ & $9.80 \times 10^{-3}$ & $9.80 \times 10^{-2}$ & $1.05 \times 10^{-1}$ & $9.93 \times 10^{-1}$ & 1.09 & 6.59 \\
\hline $\mathrm{NO}_{3}$ & $3.53 \times 10^{-4}$ & $3.94 \times 10^{-4}$ & $1.15 \times 10^{-3}$ & $1.32 \times 10^{-3}$ & $1.12 \times 10^{-2}$ & $1.18 \times 10^{-2}$ & $1.29 \times 10^{-1}$ & $1.32 \times 10^{-1}$ & 1.42 \\
\hline $\mathrm{SO}_{4}$ & $1.23 \times 10^{-3}$ & $1.85 \times 10^{-3}$ & $4.54 \times 10^{-3}$ & $4.64 \times 10^{-3}$ & $2.35 \times 10^{-2}$ & $2.24 \times 10^{-2}$ & $5.85 \times 10^{-2}$ & $5.80 \times 10^{-2}$ & $1.36 \times 10^{-1}$ \\
\hline $\mathrm{HCO}_{3}$ & $7.93 \times 10^{-4}$ & $3.11 \times 10^{-4}$ & $\mathrm{nd}^{\mathrm{d}}$ & $1.59 \times 10^{-4}$ & $n \mathrm{~d}^{\mathrm{d}}$ & $1.92 \times 10^{-4}$ & $\mathrm{nd}^{\mathrm{d}}$ & $1.95 \times 10^{-4}$ & $2.66 \times 10^{-4}$ \\
\hline
\end{tabular}

${ }^{\mathrm{a}}$ Measured at room temperature.

${ }^{\mathrm{b}}$ Magnesium and silica precipitated from the solution at $25^{\circ} \mathrm{C}$. Initial gravimetric concentrations are $\mathrm{Mg}=4.5 \times 10^{-3} \mathrm{~mol} / \mathrm{kg}$-solution and $\mathrm{Si}=7.8$ $\times 10^{-3} \mathrm{~mol} / \mathrm{kg}$-solution for Leg3 and are $\mathrm{Mg}=6.0 \times 10^{-3} \mathrm{~mol} / \mathrm{kg}$-solution and $\mathrm{Si}=5.9 \times 10^{-3} \mathrm{~mol} / \mathrm{kg}$-solution for Leg4.

${ }^{\mathrm{c}}$ Not analyzed.

${ }^{\mathrm{d}}$ Not detected. detection limits: $\mathrm{F}=0.25 \mathrm{ppm}, \mathrm{HCO}_{3}=1 \mathrm{ppm}$.

$9,12,13$, and 14 are referred to as legs $1,2,3$, and 4 throughout this paper. The solutions were prepared at room temperature using analytical grade salts. Differences between the ending and starting compositions for each leg reflect the difficulty in exactly synthesizing the solutions and changes that occur when the solution is prepared at $25^{\circ} \mathrm{C}$ and then heated to the experimental temperature of $95^{\circ} \mathrm{C}$. At the beginning of each new leg, the prepared solution did not include the undissolved solids that were present at the end of the previous leg. During the preparation of the starting solution for legs 3 and 4, an amorphous magnesium silicate precipitate formed in the $25{ }^{\circ} \mathrm{C}$ solutions. This precipitate was not removed from the starting solutions and only partially dissolved when the solution was heated up to the experimental run temperature $\left(95^{\circ} \mathrm{C}\right)$.

Evaporation was conducted in a vented, halar-lined vessel heated to $95{ }^{\circ} \mathrm{C}$ in a fluidized sand bath furnace which provided optimal heat transfer for this method. The solution was stirred constantly and HEPA (high efficiency particulate air) filtered air was streamed over the solution to help control the evaporation rate. The solution vapor was refluxed to prevent evaporative water loss as it was heated to run temperature. Once the solution was at $95^{\circ} \mathrm{C}$, the evolving water vapor was condensed into a separate container to monitor the extent of evaporation. Samples of the evaporating solution were periodically extracted and filtered at $95{ }^{\circ} \mathrm{C}$ and analyzed to determine the water chemistry. The $95^{\circ} \mathrm{C}$ filtered samples withdrawn for cation and anion analysis were immediately diluted by directly injecting the sample into a known quantity of room temperature de-ionized water to prevent precipitation on cooling. Undiluted samples withdrawn for total dissolved inorganic carbon analysis, $\Sigma \mathrm{CO}_{2}(\mathrm{aq})$, were immediately stored by filling gas tight vials to prevent equilibration with air at room temperature. Separate undiluted samples for solution $p \mathrm{H}$ were stored in a closed container and $p \mathrm{H}$ was measured as soon as they cooled to room temperature. In the last two samples of leg 4, precipitates formed in the $p \mathrm{H}$ and carbon samples as they cooled. Samples of the condensed water vapor were also periodically extracted and analyzed to monitor gas volatility. After the last sample was taken for each leg, the evaporation was continued to dryness. The solid precipitate was collected at the end of each leg of the experiment, dried in an oven at $40{ }^{\circ} \mathrm{C}$ to facilitate sample preparation, and analyzed by powder $\mathrm{x}$-ray diffraction $(\mathrm{XRD})$.

\section{B. Analytical methods}

Sample $p \mathrm{H}$ was measured at room temperature with a combination electrode, which is reliable in solutions with an ionic strength less than 0.1 molal. $^{11}$ The sample cooled to room temperature and $p \mathrm{H}$ was measured within a half hour of sampling. The $p \mathrm{H}$ measurements for legs 3 and 4 , where the ionic strength of the solution was greater than 0.1 molal, represent uncorrected values and have not been corrected for ionic strength. Total dissolved carbon, $\Sigma \mathrm{CO}_{2}(\mathrm{aq})$, was measured with an infrared carbon analyzer and had a detection limit of $1 \mathrm{ppm}$. Dissolved calcium, magnesium, silica, and sodium were measured with an inductively coupled plasmaatomic emission spectrometer, dissolved potassium was measured using an atomic absorption spectrophotometer, and fluoride, chloride, nitrate, and sulfate anions were determined using ion chromatography. Reproducibility of these techniques is typically better than $\pm 2 \%$. The mineralogical composition was determined by powdered XRD using a $\mathrm{Cu}$ $K_{\alpha}$ source from $10^{\circ}$ to $90^{\circ} 2 \theta$ at $0.02^{\circ}$ per step. The XRD instrument was calibrated using NIST traceable silicon (\# 640c) and mica (\# 675) standards for high angle and low angle peaks, respectively. XRD cannot detect amorphous solids or minerals that are present at $<2 \mathrm{wt} \%$. Mineral identification was based on the presence of the three most intense peaks in the XRD pattern for a given mineral. In some cases 
where the most intense peaks overlapped with other mineral peaks, identification was based on the presence of lower intensity diagnostic peaks.

\section{Thermodynamic modeling calculations}

Solution compositions were modeled using the EQ3/6 geochemical code, and a high temperature Pitzer ioninteraction model that is further described in Table $\mathrm{II}^{1,12-14}$ The high temperature Pitzer ion-interaction model approximates nonideal behavior of solutions at elevated ionic strength and temperature. The predictive models were generated to mirror the experimental design and analysis, in which synthetic pore water was evaporated over a discrete range for each leg, with a cumulative evaporation up to $3500 \times$ for the overall experiment. The concentration factor, $\mathrm{CF}$, can then be defined as

$$
\mathrm{CF}_{(n)}=\frac{\mathrm{H}_{2} \mathrm{O}_{(i)}}{\mathrm{H}_{2} \mathrm{O}_{(n)}},
$$

where $\mathrm{H}_{2} \mathrm{O}_{(i)}$ is the initial mass of $\mathrm{H}_{2} \mathrm{O}$ solvent and $\mathrm{H}_{2} \mathrm{O}_{(n)}$ is the mass of $\mathrm{H}_{2} \mathrm{O}$ solvent remaining after the $n$th step in the evaporation process.

The evaporation model consisted of three steps. In the first step, the measured composition of the first sample at $95^{\circ} \mathrm{C}$ (Table I, FEC\#-1) was speciated, suppressing all mineral precipitation in the calculation. At this point in the experiment, the solution was simply brought up to temperature, refluxing any water vapor to prevent evaporation. During the second step, the speciated water was evaporated by stepwise removal of solvent water at a fixed rate of $0.25 \mathrm{~mol} \mathrm{H}_{2} \mathrm{O}$ reactant per mol of solute at $95{ }^{\circ} \mathrm{C}$. In the evaporation step, all minerals were allowed to precipitate with the exception of quartz and dolomite because of known slow kinetics; glaserite, hydromagnesite, and magnesite because the available thermodynamic data are questionable; and cristobalite because it forms above $1470{ }^{\circ} \mathrm{C}$ and is not relevant to this experiment. In the speciation and evaporation steps, oxygen and carbon dioxide fugacities were fixed at $21 \%$ and $0.033 \%$, respectively, to simulate atmospheric experimental conditions. $\mathrm{A} \mathrm{CO}_{2}(\mathrm{~g})$-sink was added to the model to remove excess buildup of $\mathrm{CO}_{2}(\mathrm{~g})$ from the reaction surface. Finally, in the third step, the predicted $p \mathrm{H}$ values at $95{ }^{\circ} \mathrm{C}$ were recalculated to $25^{\circ} \mathrm{C}$ to compare with measured $p \mathrm{H}$ at room temperature. This was achieved by performing a further calculation that reduced the temperature of the reaction from 95 to $25^{\circ} \mathrm{C}$, while fixing $\Sigma \mathrm{CO}_{2}$ (aq) to the predicted $95{ }^{\circ} \mathrm{C}$ value and suppressing mineral formation. For all calculations, electrical balance was achieved by automatically changing the sodium concentration with a convergence tolerance of $0.1 \mathrm{ppb}$. Charge balancing was necessary due to analytical errors generated in the experimental analysis and also potentially incomplete analysis. The calculated activity of water was interpreted as a function of relative humidity, and predicted solution composition, $p \mathrm{H}$, and mineral composition were compared with experimental ion analysis and XRPD results with respect to the overall concentration factor. The results are shown graphically in Figs. 3 and 4, and discussed in the following sections.

\section{RESULTS}

Evaporation of the dilute water yielded a sulfate brine as predicted by chemical divide theory based on its initial $\mathrm{Ca}: \mathrm{SO}_{4}: \mathrm{HCO}_{3}$ ratio (Fig. 2). Although this water is classified as a sulfate brine, sulfate concentrations are minor compared to the concentration of sodium and chloride, which dominate the solution chemistry. At the conclusion of leg 4, sodium and chloride were 45 and $40 \mathrm{~mol} \%$, respectively, while calcium and sulfate were relatively minor constituents at 0.1 and $0.8 \mathrm{~mol} \%$, respectively (Table III). The initial experimental solution contained trace amounts of fluoride that were rapidly removed from solution presumably as highly insoluble fluorite $\left(\mathrm{CaF}_{2}\right)$ (Table I). Fluoride was not included in the model since it was not detected in the first sample analysis at $95{ }^{\circ} \mathrm{C}$ (leg 1, FEC9-1). The minerals identified by XRD in the precipitates are halite $(\mathrm{NaCl})$, bassanite $\left(2 \mathrm{CaSO}_{4} \cdot \mathrm{H}_{2} \mathrm{O}\right)$, anhydrite $\left(\mathrm{CaSO}_{4}\right)$, niter $\left(\mathrm{KNO}_{3}\right)$, and nitratine $\left(\mathrm{NaNO}_{3}\right)$, and are listed for each leg in Table IV.

We see no evidence of volatility for $\mathrm{HCl}, \mathrm{HNO}_{3}$, and $\mathrm{HF}$ gases in these experiments. Concentrations of fluoride, chloride, nitrate, and sulfate in the condensed vapor were all below the detection limits. This is in contrast to evaporation of a concentrated calcium chloride type water at around $140{ }^{\circ} \mathrm{C}$ (based on the $1000 \times$ solution results from Rosenberg et $\left.a l^{5}\right)$ where significant volatilization of $\mathrm{HCl}(\mathrm{g})$ was measured by acidic condensates at $90 \%$ evaporation at $\sim 75000 \times .{ }^{15}$ While our evaporation is less than the aforementioned research, our results indicate that gas volatility is not a major concern for the evaporation and concentration of sulfate waters at $95{ }^{\circ} \mathrm{C}$ and $\sim 3400 \times$.

Figures 3 and 4 show the experimental and predicted solution composition and the predicted mineral precipitation as a function of overall concentration factor. There is excellent agreement between the model predictions of potassium and nitrate concentrations with those measured by experiment. Solution data show conservative concentration of both potassium and nitrate in each evaporation leg, indicating no mineral precipitation [Figs. 3(a) and 4]. This is supported by the XRD data where only a small amount of niter was identified in the last leg after the solution had completely evaporated when precipitation of all mineral phases is expected (Table IV). Calculations required the suppression of pentasalt (gorgeyite, $\mathrm{K}_{2} \mathrm{Ca}_{5}\left(\mathrm{SO}_{4}\right)_{6} \cdot \mathrm{H}_{2} \mathrm{O}$ ) precipitation at a concentration factor above $1000 \times$ in leg 4 [Fig. 3(a)] to achieve agreement with experimental solution composition and solid characterization. Pentasalt was not detected by XRD analysis.

For sodium and chloride behavior, we observe good agreement between experimental composition and model prediction [Figs. 3(b) and 4]. Both ions concentrate in solution with increasing evaporation until the solution is saturated with respect to halite. Halite is the dominant salt in samples taken to dryness and identified by XRD (Table IV). There is a discrepancy between the experimental sodium concentration and that predicted by the model in leg 1, due to the charge balance correction using sodium ions in the model. This observation is explained by the overprediction of positively charged magnesium, and the subsequent de- 
TABLE II. Temperature dependence of Pitzer interaction parameters. $25^{\circ} \mathrm{C}$-centric equation used to derive parameters: $\chi_{(T)}=a_{1}+a_{2}[\{1 / T\}-\{1 / 298.15\}]$ $+a_{3} \ln \{T / 298.15\}+a_{4}\{T-298.15\}$.

Pitzer interaction parameters

\begin{tabular}{|c|c|c|c|c|c|c|c|}
\hline \multirow{2}{*}{\multicolumn{2}{|c|}{$\begin{array}{l}\text { Ion } \\
\text { interactions }\end{array}$}} & \multirow[b]{2}{*}{ Coefficients } & & \multirow[b]{2}{*}{ Reference } \\
\hline & & & $a_{1}$ & $a_{2}$ & $a_{3}$ & $a_{4}$ & \\
\hline \multirow[t]{4}{*}{$\mathrm{Ca}^{++}$} & \multirow[t]{4}{*}{$\mathrm{Cl}^{-}$} & $\beta_{M X}^{(0)}$ & $4.46 \times 10^{-1}$ & $2.21 \times 10^{2}$ & $1.61 \times 10^{-11}$ & $2.28 \times 10^{-4}$ & Sterner et al. ${ }^{34}$ \\
\hline & & $\beta_{M X}^{(1)}$ & $-1.66 \times 10$ & $-8.83 \times 10^{3}$ & $7.10 \times 10^{-11}$ & $-2.49 \times 10^{-2}$ & \\
\hline & & $\beta_{M X}^{(2)}$ & 0.00 & 0.00 & 0.00 & 0.00 & \\
\hline & & $\mathrm{C}_{M X}^{\phi}$ & $-1.73 \times 10^{-2}$ & $-1.30 \times 10^{1}$ & $-3.87 \times 10^{-13}$ & $-3.15 \times 10^{-5}$ & \\
\hline \multirow[t]{4}{*}{$\mathrm{Ca}^{++}$} & \multirow{4}{*}{$\mathrm{HCO}_{3}^{-}$} & $\beta_{M X}^{(0)}$ & $4.00 \times 10^{-1}$ & 0.00 & 0.00 & 0.00 & Pitzer ${ }^{13}$ \\
\hline & & $\beta_{M X}^{(1)}$ & 2.98 & 0.00 & 0.00 & 0.00 & \\
\hline & & $\beta_{M X}^{(2)}$ & 0.00 & 0.00 & 0.00 & 0.00 & \\
\hline & & $\mathrm{C}_{M X}^{\phi}$ & 0.00 & 0.00 & 0.00 & 0.00 & \\
\hline \multirow[t]{4}{*}{$\mathrm{Ca}^{++}$} & \multirow[t]{4}{*}{$\mathrm{HSO}_{4}^{-}$} & $\beta_{M X}^{(0)}$ & $2.15 \times 10^{-1}$ & 0.00 & 0.00 & 0.00 & Pitzer ${ }^{13}$ \\
\hline & & $\beta_{M X}^{(1)}$ & 2.53 & 0.00 & 0.00 & 0.00 & \\
\hline & & $\beta_{M X}^{(2)}$ & 0.00 & 0.00 & 0.00 & 0.00 & \\
\hline & & $\mathrm{C}_{M X}^{\phi}$ & 0.00 & 0.00 & 0.00 & 0.00 & \\
\hline \multirow[t]{4}{*}{$\mathrm{Ca}^{++}$} & \multirow[t]{4}{*}{$\mathrm{NO}_{3}^{-}$} & $\beta_{M X}^{(0)}$ & $1.48 \times 10^{-1}$ & $-4.88 \times 10^{1}$ & $-7.47 \times 10^{-2}$ & $-1.70 \times 10^{-4}$ & Oakes and Felmy ${ }^{28}$ \\
\hline & & $\beta_{M X}^{(1)}$ & 2.44 & $-2.24 \times 10^{4}$ & $-9.93 \times 10^{1}$ & $1.19 \times 10^{-1}$ & \\
\hline & & $\beta_{M X}^{(2)}$ & 0.00 & 0.00 & 0.00 & 0.00 & \\
\hline & & $\mathrm{C}_{M X}^{\phi}$ & $-4.12 \times 10^{-3}$ & $-1.79 \times 10^{1}$ & $-1.19 \times 10^{-1}$ & $1.87 \times 10^{-4}$ & \\
\hline \multirow[t]{4}{*}{$\mathrm{Ca}^{++}$} & \multirow[t]{4}{*}{$\mathrm{SO}_{4}^{--}$} & $\beta_{M X}^{(0)}$ & $1.50 \times 10^{-1}$ & 0.00 & 0.00 & 0.00 & Greenberg and Moller ${ }^{21}$ \\
\hline & & $\beta_{M X}^{(1)}$ & 3.00 & 0.00 & 0.00 & 0.00 & \\
\hline & & $\beta_{M X}^{(2)}$ & 0.00 & 0.00 & 0.00 & 0.00 & \\
\hline & & $\mathrm{C}_{M X}^{\phi}$ & 0.00 & 0.00 & 0.00 & 0.00 & \\
\hline \multirow[t]{4}{*}{$\mathrm{H}^{+}$} & \multirow[t]{4}{*}{$\mathrm{Cl}^{-}$} & $\beta_{M X}^{(0)}$ & $1.77 \times 10^{-1}$ & $-3.35 \times 10^{1}$ & $-2.62 \times 10^{-1}$ & $1.26 \times 10^{-4}$ & Holmes et al. ${ }^{27}$ \\
\hline & & $\beta_{M X}^{(1)}$ & $2.93 \times 10^{-1}$ & $3.40 \times 10^{3}$ & $1.98 \times 10^{1}$ & $-2.79 \times 10^{-2}$ & \\
\hline & & $\beta_{M X}^{(2)}$ & 0.00 & 0.00 & 0.00 & 0.00 & \\
\hline & & $\mathrm{C}_{M X}^{\phi}$ & $3.62 \times 10^{-4}$ & $-2.91 \times 10^{-11}$ & 0.00 & $-3.04 \times 10^{-5}$ & \\
\hline $\mathrm{H}^{+}$ & $\mathrm{HSO}_{4}^{-}$ & $\beta_{M X}^{(0)}$ & $2.09 \times 10^{-1}$ & $1.05 \times 10^{3}$ & 5.96 & $-8.78 \times 10^{-3}$ & Holmes and Mesmer 24 \\
\hline & & $\beta_{M X}^{(1)}$ & $4.41 \times 10^{-1}$ & $2.96 \times 10^{2}$ & 2.37 & $-4.63 \times 10^{-3}$ & \\
\hline & & $\beta_{M X}^{(2)}$ & 0.00 & 0.00 & 0.00 & 0.00 & \\
\hline & & $\mathrm{C}_{M X}^{\phi}$ & 0.00 & 0.00 & 0.00 & 0.00 & \\
\hline $\mathrm{H}^{+}$ & $\mathrm{NO}_{3}^{-}$ & $\beta_{M X}^{(0)}$ & $1.26 \times 10^{-1}$ & $5.60 \times 10^{2}$ & 4.92 & $-9.95 \times 10^{-3}$ & Felmy et al. ${ }^{32}$ \\
\hline & & $\beta_{M X}^{(1)}$ & $2.88 \times 10^{-1}$ & $2.71 \times 10^{-7}$ & $1.59 \times 10^{-9}$ & $1.34 \times 10^{-3}$ & \\
\hline & & $\beta_{M X}^{(2)}$ & 0.00 & 0.00 & 0.00 & 0.00 & \\
\hline & & $\mathrm{C}_{M X}^{\phi}$ & $-5.60 \times 10^{-3}$ & -6.58 & $-5.77 \times 10^{-2}$ & $1.10 \times 10^{-4}$ & \\
\hline $\mathrm{H}^{+}$ & $\mathrm{SO}_{4}^{--}$ & $\beta_{M X}^{(0)}$ & $9.86 \times 10^{-2}$ & $-6.70 \times 10^{3}$ & $-4.17 \times 10^{1}$ & $6.37 \times 10^{-2}$ & Pabalan and Pitzer ${ }^{47}$ \\
\hline & & $\beta_{M X}^{(1)}$ & 0.00 & 0.00 & 0.00 & 0.00 & \\
\hline & & $\beta_{M X}^{(2)}$ & 0.00 & 0.00 & 0.00 & 0.00 & \\
\hline & & $\mathrm{C}_{M X}^{\phi}$ & $5.93 \times 10^{-2}$ & $-3.03 \times 10^{3}$ & $-1.61 \times 10^{1}$ & $2.02 \times 10^{-2}$ & \\
\hline $\mathrm{K}^{+}$ & $\mathrm{Cl}^{-}$ & $\beta_{M X}^{(0)}$ & $4.78 \times 10^{-2}$ & $-3.43 \times 10^{2}$ & -1.38 & $1.34 \times 10^{-3}$ & Greenberg and Moller ${ }^{21}$ \\
\hline & & $\beta_{M X}^{(1)}$ & $2.16 \times 10^{-1}$ & $-5.76 \times 10^{2}$ & -2.88 & $4.64 \times 10^{-3}$ & \\
\hline & & $\beta_{M X}^{(2)}$ & 0.00 & 0.00 & 0.00 & 0.00 & \\
\hline & & $\mathrm{C}_{M X}^{\phi}$ & $-7.49 \times 10^{-4}$ & $3.65 \times 10^{1}$ & $1.48 \times 10^{-1}$ & $-1.47 \times 10^{-4}$ & \\
\hline $\mathrm{K}^{+}$ & $\mathrm{CO}_{3}^{--}$ & $\beta_{M X}^{(0)}$ & $1.29 \times 10^{-1}$ & 0.00 & 0.00 & 0.00 & Pitzer ${ }^{13}$ \\
\hline & & $\beta_{M X}^{(1)}$ & 1.43 & 0.00 & 0.00 & 0.00 & \\
\hline & & $\beta_{M X}^{(2)}$ & 0.00 & 0.00 & 0.00 & 0.00 & \\
\hline & & $\mathrm{C}_{M X}^{\phi}$ & $4.99 \times 10^{-4}$ & 0.00 & 0.00 & 0.00 & \\
\hline $\mathrm{K}^{+}$ & $\mathrm{F}^{-}$ & $\beta_{M X}^{(0)}$ & $8.09 \times 10^{-2}$ & 0.00 & 0.00 & 0.00 & Pitzer ${ }^{13}$ \\
\hline & & $\beta_{M X}^{(1)}$ & $2.02 \times 10^{-1}$ & 0.00 & 0.00 & 0.00 & \\
\hline & & $\beta_{M X}^{(2)}$ & 0.00 & 0.00 & 0.00 & 0.00 & \\
\hline & & $\mathrm{C}_{M X}^{\phi}$ & $9.30 \times 10^{-4}$ & 0.00 & 0.00 & 0.00 & \\
\hline $\mathrm{K}^{+}$ & $\mathrm{HCO}_{3}^{-}$ & $\beta_{M X}^{(0)}$ & $-1.07 \times 10^{-2}$ & 0.00 & 0.00 & 0.00 & Pitzer ${ }^{13}$ \\
\hline & & $\beta_{M X}^{(1)}$ & $4.78 \times 10^{-2}$ & 0.00 & 0.00 & 0.00 & \\
\hline & & $\beta_{M X}^{(2)}$ & 0.00 & 0.00 & 0.00 & 0.00 & \\
\hline & & $\mathrm{C}_{M X}^{\phi}$ & 0.00 & 0.00 & 0.00 & 0.00 & \\
\hline $\mathrm{K}^{+}$ & $\mathrm{HSO}_{4}^{-}$ & $\beta_{M X}^{(0)}$ & $-3.00 \times 10^{-4}$ & 0.00 & 0.00 & 0.00 & Pitzer ${ }^{13}$ \\
\hline & & $\beta_{M X}^{(1)}$ & $1.74 \times 10^{-1}$ & 0.00 & 0.00 & 0.00 & \\
\hline & & $\beta_{M X}^{(2)}$ & 0.00 & 0.00 & 0.00 & 0.00 & \\
\hline & & $\mathrm{C}_{M X}^{\phi}$ & 0.00 & 0.00 & 0.00 & 0.00 & \\
\hline
\end{tabular}


TABLE II. (Continued.)

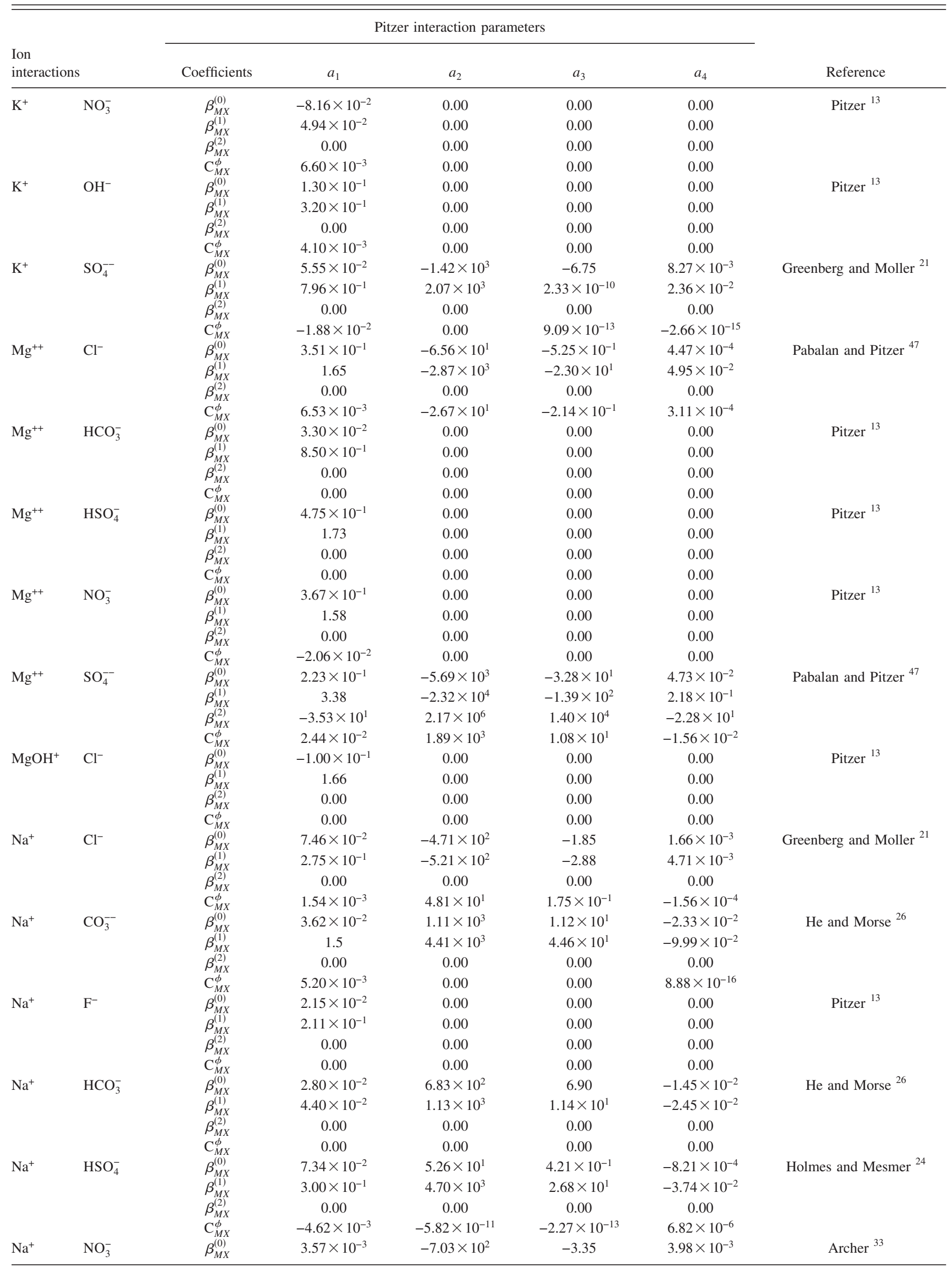


TABLE II. (Continued.)

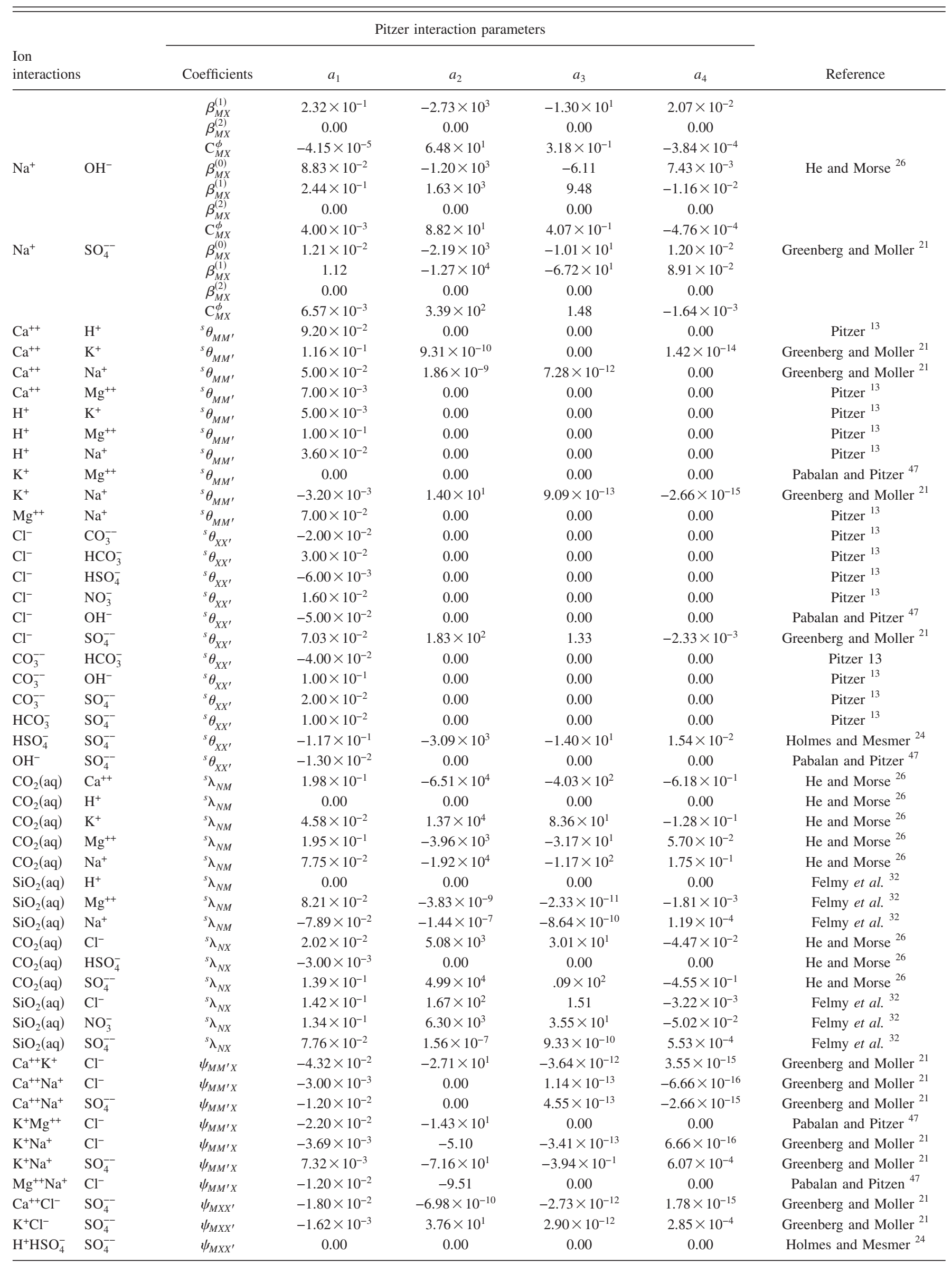


TABLE II. (Continued.)

\begin{tabular}{|c|c|c|c|c|c|c|c|}
\hline \multicolumn{2}{|l|}{$\begin{array}{l}\text { Ion } \\
\text { interactions }\end{array}$} & Coefficients & $a_{1}$ & $a_{2}$ & $a_{3}$ & $a_{4}$ & Reference \\
\hline $\mathrm{Na}^{+} \mathrm{Cl}^{-}$ & $\mathrm{OH}^{-}$ & $\psi_{M X X^{\prime}}$ & $-6.01 \times 10^{-3}$ & -9.93 & 0.00 & 0.00 & Pabalan and Pitzer ${ }^{47}$ \\
\hline $\mathrm{Na}^{+} \mathrm{Cl}^{-}$ & $\mathrm{SO}_{4}^{--}$ & $\psi_{M X X^{\prime}}$ & $-9.09 \times 10^{-3}$ & $-7.86 \times 10^{1}$ & $-5.52 \times 10^{-1}$ & $9.46 \times 10^{-4}$ & Greenberg and Moller ${ }^{21}$ \\
\hline $\mathrm{CO}_{2}(\mathrm{aq})$ & $\mathrm{Ca}^{++} \mathrm{Cl}^{-}$ & $\xi_{N M X}$ & $-1.61 \times 10^{-2}$ & $6.25 \times 10^{3}$ & $3.90 \times 10^{1}$ & $-6.04 \times 10^{-2}$ & $\mathrm{He}$ and Morse 26 \\
\hline $\mathrm{CO}_{2}(\mathrm{aq})$ & $\mathrm{H}^{+} \mathrm{Cl}^{-}$ & $\xi_{N M X}$ & $-4.65 \times 10^{-3}$ & $-1.31 \times 10^{3}$ & -7.26 & $9.96 \times 10^{-3}$ & He and Morse ${ }^{26}$ \\
\hline $\mathrm{CO}_{2}(\mathrm{aq})$ & $\mathrm{H}^{+} \mathrm{SO}_{4}^{--}$ & $\xi_{N M X}$ & 0.00 & 0.00 & 0.00 & 0.00 & $\mathrm{He}$ and Morse ${ }^{26}$ \\
\hline $\mathrm{CO}_{2}(\mathrm{aq})$ & $\mathrm{K}^{+} \mathrm{Cl}^{-}$ & $\xi_{N M X}$ & $-1.27 \times 10^{-2}$ & $-9.33 \times 10^{3}$ & $-5.65 \times 10^{1}$ & $8.56 \times 10^{-2}$ & $\mathrm{He}$ and Morse ${ }^{26}$ \\
\hline $\mathrm{CO}_{2}(\mathrm{aq})$ & $\mathrm{K}^{+} \mathrm{SO}_{4}^{--}$ & $\xi_{N M X}$ & $-4.10 \times 10^{-4}$ & $-1.12 \times 10^{5}$ & $-6.84 \times 10^{2}$ & 1.04 & $\mathrm{He}$ and Morse ${ }^{26}$ \\
\hline $\mathrm{CO}_{2}(\mathrm{aq})$ & $\mathrm{Mg}^{++} \mathrm{Cl}^{-}$ & $\xi_{N M X}$ & $-1.53 \times 10^{-2}$ & $-3.32 \times 10^{3}$ & $-1.97 \times 10^{1}$ & $2.94 \times 10^{-2}$ & $\mathrm{He}$ and Morse ${ }^{26}$ \\
\hline $\mathrm{SiO}_{2}(\mathrm{aq})$ & $\mathrm{Mg}^{++} \mathrm{Cl}^{-}$ & $\xi_{N M X}$ & $-5.15 \times 10^{-2}$ & $1.50 \times 10^{-8}$ & $8.99 \times 10^{-11}$ & $5.94 \times 10^{-4}$ & Felmy et al. ${ }^{32}$ \\
\hline $\mathrm{SiO}_{2}(\mathrm{aq})$ & $\mathrm{Na}^{+} \mathrm{Cl}^{-}$ & $\xi_{N M X}$ & $-8.48 \times 10^{-15}$ & $-1.84 \times 10^{-8}$ & $-1.11 \times 10^{-10}$ & $-2.00 \times 10^{-4}$ & Felmy et al. ${ }^{32}$ \\
\hline
\end{tabular}

crease in calculated sodium concentration to neutralize the charge discrepancy. The charge balance correction resulted in a sodium concentration that differed from the original (measured) concentration by $21 \%$ in the first leg, $13 \%$ in the second leg, $1 \%$ in the third leg, and $5 \%$ in the fourth leg. Since sodium saturation did not occur until the formation of halite late in fourth leg, we believe this sodium correction did not significantly affect the quality of our calculations.

There is also good agreement between experimental compositions and model prediction for calcium and sulfate [Figs. 3(c) and 4]. At a concentration factor of roughly 10 $X$ in leg 2 , both calcium and sulfate begin to precipitate as can be seen in the decrease in their slopes. Although calcium sulfate precipitation continues over the duration of the experiment, dissolved calcium decreases as the sulfate in-

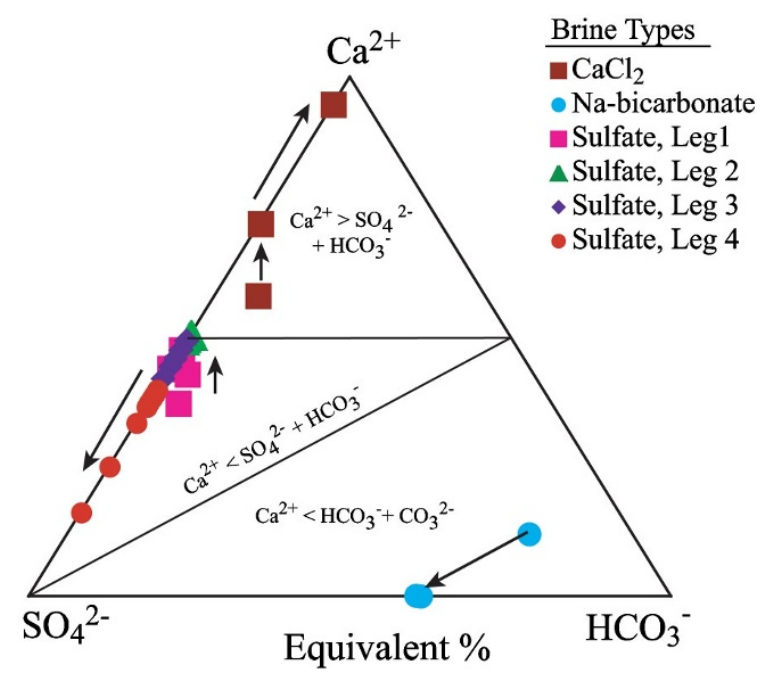

FIG. 2. (Color) Chemical evolution of dilute calcium chloride (synthetic Topopah Spring tuff porewater-Ref. 5), Na-bicarbonate (synthetic J-13 groundwater-Ref. 5), and sulfate (synthetic Topopah Spring tuff porewater, this study) waters upon evaporation. creases with continued evaporation at a concentration factor of about $1000 \times$. This is consistent with the chemical divide theory and the initial composition of the water which contained $\mathrm{SO}_{4}: \mathrm{Ca}>1$. This behavior was best modeled by using bassanite as the solubility limiting phase (using gypsum or anhydrite resulted in an overprediction and underprediction, respectively, of the calcium and sulfate concentrations). This finding is in partial agreement with the experiments, which identified both anhydrite and bassanite (Table IV). This difference may be an artifact of the experimental protocol because calcium sulfate hydration states can be readily altered by changes in temperature and humidity, such as those found in the drying and preparation of the precipitate prior to XRD analysis. The model overestimates calcium and sulfate by about a factor of 2 in concentrated brines $(1000 \times$ concentration factor), and appears to increase with continued evaporation. It is possible that the overprediction in calcium and sulfate concentrations observed using bassanite and gypsum solubility controls, and the underprediction observed with anhydrite controls indicates a metastable mixture of these solubility limiting phases.

Comparison between both magnesium and silica experimental concentrations and model predictions during the evaporation show reasonable agreement in legs 2 and 3 and only fair agreement in legs 1 and 4 [Fig. 3(f)]. Experiment and prediction both show that magnesium and silica are removed from solution as solid precipitates. The model predicts that sepiolite, amorphous silica, and brucite are the solubility controls (Fig. 4). These phases were not observed in the experiment possibly because the amount was too small to be detected or because they were amorphous. It is possible that a noncrystalline magnesium silicate phase precipitated, similar to the solid that formed at $25{ }^{\circ} \mathrm{C}$ (Legs 3 and 4). ${ }^{16}$ The Pitzer database contained only two magnesium silicate minerals, talc $\left(\mathrm{Mg}_{3} \mathrm{Si}_{4} \mathrm{O}_{10}(\mathrm{OH})_{2}\right)$ and sepiolite 

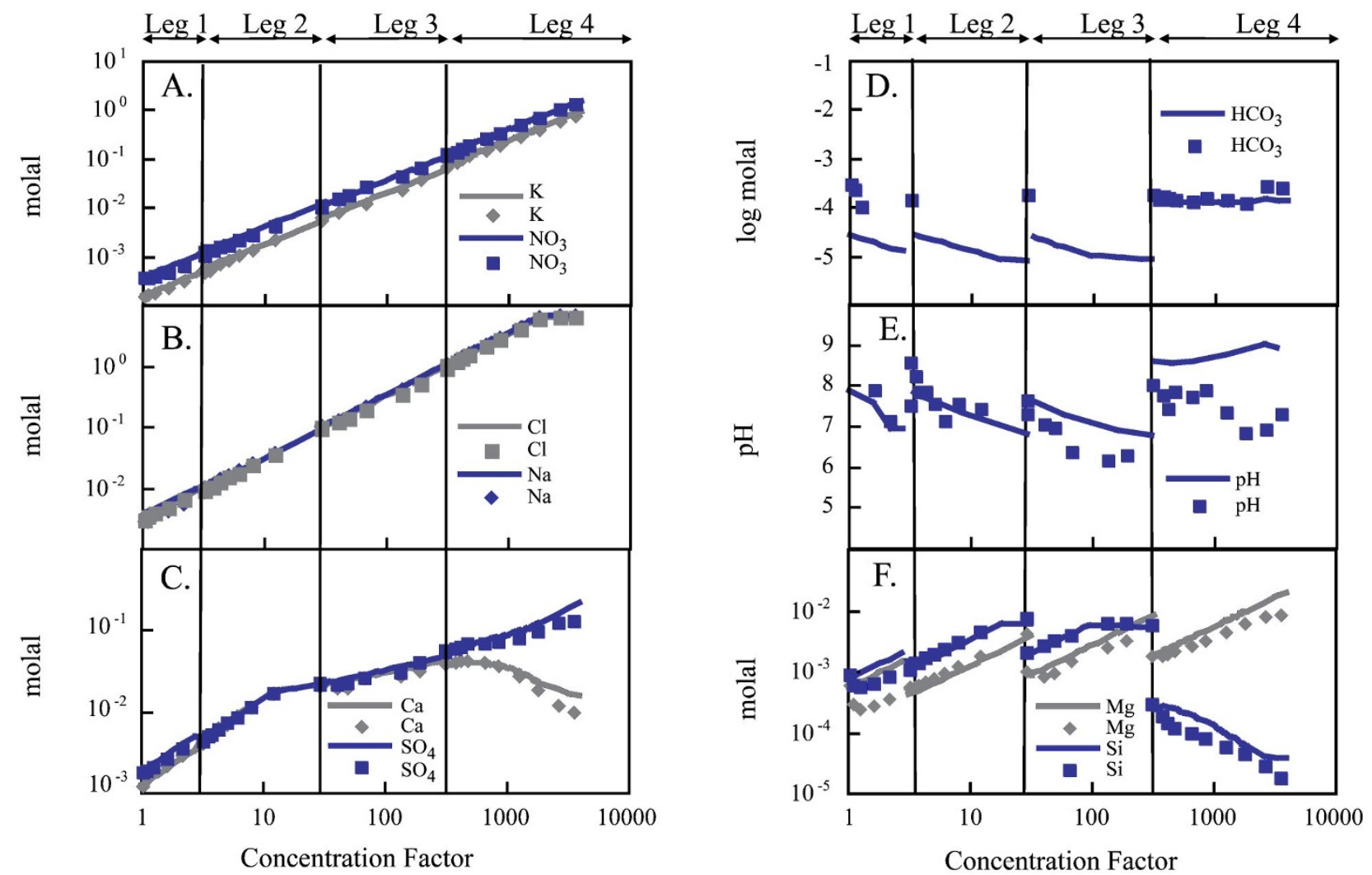

FIG. 3. (Color) Evaporation of dilute sulfate water based on a Topopah Spring tuff porewater chemistry. Comparison of experimental and model solution concentrations vs concentration factor. Symbols indicate experimental data and lines indicate model data.

$\left(\mathrm{Mg}_{4} \mathrm{Si}_{6} \mathrm{O}_{15}(\mathrm{OH})_{2} \cdot 6 \mathrm{H}_{2} \mathrm{O}\right)$. A better model fit was achieved when sepiolite was allowed to precipitate and talc formation was suppressed.

There is good agreement between the experimental and predicted total dissolved carbonate in the final leg [shown in Fig. 3(d) as $\left.\Sigma \mathrm{CO}_{2}(\mathrm{aq})\right]$, assuming equilibrium with atmospheric $\mathrm{CO}_{2}(\mathrm{~g})$ at temperature. In more dilute legs 1 to 3 , total dissolved carbonate was not detected after the first few samples for each leg. Predicted carbonate concentrations for legs 1, 2, and 3 are all below the detection limit and are consistent with the experiment. The failure of the model to capture the initial dissolved carbonate concentrations suggests that $\Sigma \mathrm{CO}_{2}(\mathrm{aq})$ in starting solution synthesized at $25{ }^{\circ} \mathrm{C}$ had not degassed to the lower equilibrium amount at $95{ }^{\circ} \mathrm{C}$. Model predictions show that carbonate concentrations decrease throughout the evaporation process as carbonate is lost to the atmosphere as gaseous $\mathrm{CO}_{2}$ in conjunction with a decreasing $p \mathrm{H}$. No carbonate minerals were predicted to form until leg 4 , where a very small amount of calcite precipitates, which was too small to be detected by XRD.

Model prediction of $p \mathrm{H}$ in the first two legs is in reasonable agreement with experimental data showing that the $p \mathrm{H}$ values decrease during the evaporation in each leg [Fig. 3(e)]. However, in legs 3 and 4 where the ionic strength exceeds 0.1 molal, measured $p \mathrm{H}$ values are uncorrected and are as much as $2 p \mathrm{H}$ units lower than the predicted $p \mathrm{H}$. The measured values were not corrected for ionic strength effects in these complex solutions. Rai and Felmy ${ }^{17}$ report that measured $p \mathrm{H}$ will be lower than the actual $p \mathrm{H}$ by 0.14 units in 1 molal $\mathrm{NaCl}$ and by $0.970 .97 p \mathrm{H}$ in 6 molal $\mathrm{NaCl}$ due to the ionic strength effects on the liquid junction potential of a commercially available $3 \mathrm{M} \mathrm{KCl}$ combination electrode similar to that used in these experiments. Even larger discrepancies between measured and real $p \mathrm{H}$ values are seen in more complex systems containing mixtures of mono and divalent ions at high ionic strength. The difference in measured $p \mathrm{H}$ at the end of one leg and the start of the next leg is an artifact of the experimental protocol. The waters were synthesized at room temperature, equilibrated with atmospheric $\mathrm{CO}_{2}(\mathrm{~g})$ and have higher dissolved carbon and higher $p \mathrm{H}$ than they possess at $95^{\circ} \mathrm{C}$.

Accurate prediction of $p \mathrm{H}$ is very important because the solubility of many solid phases, such as sepiolite, calcite, and amorphous silica are strongly influenced by solution $p \mathrm{H}$. Therefore, it is possible that the discrepancy between experimental and predicted values of magnesium, silica, and cal-

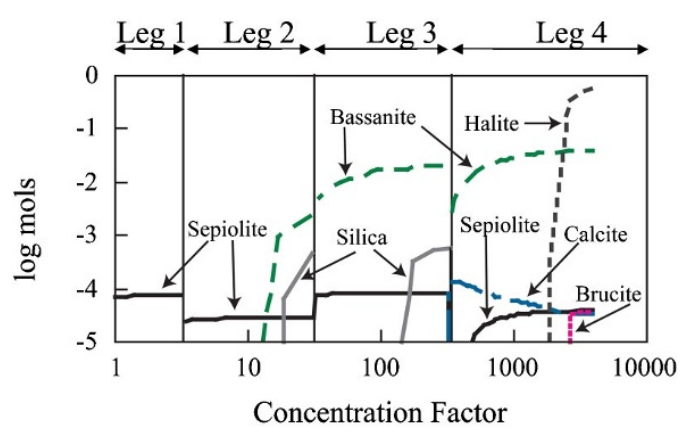

FIG. 4. (Color) Evaporation of dilute sulfate water based on a Topopah Spring tuff porewater chemistry. Predicted mineral amounts vs concentration factor. 
TABLE III. Concentration (molal) of a synthetic "sulfate type" Topopah Spring Tuff pore water as it evaporated at $95^{\circ} \mathrm{C}$.

\begin{tabular}{|c|c|c|c|c|c|c|c|c|c|c|c|c|}
\hline & Sample & $\begin{array}{l}\text { Concentration } \\
\text { factor }\end{array}$ & $p \mathrm{H}^{\mathrm{a}}$ & $\mathrm{HCO}_{3}^{-}$ & $\mathrm{Ca}$ & $\mathrm{Mg}$ & $\mathrm{Si}$ & $\mathrm{Na}$ & $\mathrm{K}$ & $\mathrm{Cl}$ & $\mathrm{NO}_{3}$ & $\mathrm{SO}_{4}$ \\
\hline \multirow[t]{6}{*}{ Leg 1} & FEC9-1 & 1.00 & $\mathrm{na}^{\mathrm{b}}$ & $3.11 \times 10^{-4}$ & $1.25 \times 10^{-3}$ & $6.48 \times 10^{-4}$ & $9.21 \times 10^{-4}$ & $3.04 \times 10^{-3}$ & $1.63 \times 10^{-4}$ & $3.31 \times 10^{-3}$ & $3.94 \times 10^{-4}$ & $1.85 \times 10^{-3}$ \\
\hline & FEC9-2 & 1.07 & $\mathrm{na}^{\mathrm{b}}$ & $2.46 \times 10^{-4}$ & $1.64 \times 10^{-3}$ & $3.11 \times 10^{-4}$ & $6.27 \times 10^{-4}$ & $3.11 \times 10^{-3}$ & $1.73 \times 10^{-4}$ & $3.56 \times 10^{-3}$ & $3.97 \times 10^{-4}$ & $1.95 \times 10^{-3}$ \\
\hline & FEC9-3 & 1.23 & $\mathrm{na}^{\mathrm{b}}$ & $1.16 \times 10^{-4}$ & $1.91 \times 10^{-3}$ & $2.56 \times 10^{-4}$ & $6.07 \times 10^{-4}$ & $3.68 \times 10^{-3}$ & $1.99 \times 10^{-4}$ & $4.06 \times 10^{-3}$ & $4.48 \times 10^{-4}$ & $2.23 \times 10^{-3}$ \\
\hline & FEC9-4 & 1.55 & 7.94 & $\mathrm{nd}^{\mathrm{c}}$ & $2.31 \times 10^{-3}$ & $2.95 \times 10^{-4}$ & $6.97 \times 10^{-4}$ & $4.42 \times 10^{-3}$ & $2.46 \times 10^{-4}$ & $5.09 \times 10^{-3}$ & $5.27 \times 10^{-4}$ & $2.80 \times 10^{-3}$ \\
\hline & FEC9-5 & 2.08 & 7.18 & $\mathrm{nd}^{\mathrm{c}}$ & $3.11 \times 10^{-3}$ & $3.86 \times 10^{-4}$ & $8.86 \times 10^{-4}$ & $5.93 \times 10^{-3}$ & $3.37 \times 10^{-4}$ & $6.97 \times 10^{-3}$ & $6.94 \times 10^{-4}$ & $3.74 \times 10^{-3}$ \\
\hline & FEC9-6 & 3.15 & 7.57 & $\mathrm{nd}^{\mathrm{c}}$ & $4.36 \times 10^{-3}$ & $5.58 \times 10^{-4}$ & $1.15 \times 10^{-3}$ & $9.23 \times 10^{-3}$ & $5.15 \times 10^{-4}$ & $1.00 \times 10^{-2}$ & $1.15 \times 10^{-3}$ & $4.54 \times 10^{-3}$ \\
\hline \multirow[t]{9}{*}{ Leg 2} & FEC12-1 & 3.15 & 8.6 & $1.59 \times 10^{-4}$ & $4.69 \times 10^{-3}$ & $6.05 \times 10^{-4}$ & $1.38 \times 10^{-3}$ & $1.10 \times 10^{-2}$ & $5.82 \times 10^{-4}$ & $9.80 \times 10^{-3}$ & $1.32 \times 10^{-3}$ & $4.64 \times 10^{-3}$ \\
\hline & FEC12-2 & 3.44 & 8.29 & $\mathrm{nd}^{\mathrm{c}}$ & $5.12 \times 10^{-3}$ & $6.05 \times 10^{-4}$ & $1.46 \times 10^{-3}$ & $1.20 \times 10^{-2}$ & $5.65 \times 10^{-4}$ & $1.08 \times 10^{-2}$ & $1.40 \times 10^{-3}$ & $5.12 \times 10^{-3}$ \\
\hline & FEC12-3 & 3.63 & 7.91 & $\mathrm{nd}^{\mathrm{c}}$ & $5.43 \times 10^{-3}$ & $6.17 \times 10^{-4}$ & $1.51 \times 10^{-3}$ & $1.28 \times 10^{-2}$ & $6.70 \times 10^{-4}$ & $1.14 \times 10^{-2}$ & $1.45 \times 10^{-3}$ & $5.42 \times 10^{-3}$ \\
\hline & FEC12-4 & 4.23 & 7.87 & $\mathrm{nd}^{\mathrm{c}}$ & $6.53 \times 10^{-3}$ & $7.08 \times 10^{-4}$ & $1.77 \times 10^{-3}$ & $1.53 \times 10^{-2}$ & $7.70 \times 10^{-4}$ & $1.37 \times 10^{-2}$ & $1.69 \times 10^{-3}$ & $6.46 \times 10^{-3}$ \\
\hline & FEC12-5 & 4.85 & 7.59 & $\mathrm{nd}^{\mathrm{c}}$ & $7.49 \times 10^{-3}$ & $8.14 \times 10^{-4}$ & $2.05 \times 10^{-3}$ & $1.74 \times 10^{-2}$ & $8.91 \times 10^{-4}$ & $1.62 \times 10^{-2}$ & $1.92 \times 10^{-3}$ & $7.65 \times 10^{-3}$ \\
\hline & FEC12-6 & 5.93 & 7.19 & $\mathrm{nd}^{\mathrm{c}}$ & $9.25 \times 10^{-3}$ & $9.95 \times 10^{-4}$ & $2.53 \times 10^{-3}$ & $2.16 \times 10^{-2}$ & $1.15 \times 10^{-3}$ & $1.91 \times 10^{-2}$ & $2.29 \times 10^{-3}$ & $9.00 \times 10^{-3}$ \\
\hline & FEC12-7 & 7.65 & 7.61 & $\mathrm{nd}^{\mathrm{c}}$ & $1.17 \times 10^{-2}$ & $1.26 \times 10^{-3}$ & $3.18 \times 10^{-3}$ & $2.72 \times 10^{-2}$ & $1.42 \times 10^{-3}$ & $2.49 \times 10^{-2}$ & $2.92 \times 10^{-3}$ & $1.17 \times 10^{-2}$ \\
\hline & FEC12-8 & 11.79 & 7.47 & $\mathrm{nd}^{\mathrm{c}}$ & $1.77 \times 10^{-2}$ & $1.92 \times 10^{-3}$ & $4.79 \times 10^{-3}$ & $4.14 \times 10^{-2}$ & $2.28 \times 10^{-3}$ & $3.79 \times 10^{-2}$ & $4.43 \times 10^{-3}$ & $1.77 \times 10^{-2}$ \\
\hline & FEC12-9 & 28.42 & 7.32 & $\mathrm{nd}^{\mathrm{c}}$ & $2.25 \times 10^{-2}$ & $4.52 \times 10^{-3}$ & $7.91 \times 10^{-3}$ & $1.05 \times 10^{-1}$ & $5.66 \times 10^{-3}$ & $9.80 \times 10^{-2}$ & $1.12 \times 10^{-2}$ & $2.35 \times 10^{-2}$ \\
\hline \multirow[t]{7}{*}{ Leg 3} & FEC13-1 & 28.42 & 7.69 & $1.92 \times 10^{-4}$ & $2.17 \times 10^{-2}$ & $1.06 \times 10^{-3}$ & $2.24 \times 10^{-3}$ & $1.11 \times 10^{-1}$ & $6.54 \times 10^{-3}$ & $1.05 \times 10^{-1}$ & $1.18 \times 10^{-2}$ & $2.24 \times 10^{-2}$ \\
\hline & FEC13-2 & 38.63 & 7.07 & $n d^{\mathrm{c}}$ & $2.06 \times 10^{-2}$ & $8.99 \times 10^{-4}$ & $2.87 \times 10^{-3}$ & $1.37 \times 10^{-1}$ & $8.90 \times 10^{-3}$ & $1.29 \times 10^{-1}$ & $1.64 \times 10^{-2}$ & $2.28 \times 10^{-2}$ \\
\hline & FEC13-3 & 47.95 & 6.99 & $\mathrm{nd}^{\mathrm{c}}$ & $2.04 \times 10^{-2}$ & $9.80 \times 10^{-4}$ & $3.38 \times 10^{-3}$ & $1.57 \times 10^{-1}$ & $1.27 \times 10^{-2}$ & $1.52 \times 10^{-1}$ & $2.00 \times 10^{-2}$ & $2.42 \times 10^{-2}$ \\
\hline & FEC13-4 & 64.87 & 6.4 & $\mathrm{nd}^{\mathrm{c}}$ & $2.71 \times 10^{-2}$ & $1.54 \times 10^{-3}$ & $4.24 \times 10^{-3}$ & $2.37 \times 10^{-1}$ & $1.34 \times 10^{-2}$ & $2.00 \times 10^{-1}$ & $2.89 \times 10^{-2}$ & $2.80 \times 10^{-2}$ \\
\hline & FEC13-5 & 129.02 & 6.21 & $\mathrm{nd}^{\mathrm{c}}$ & $2.91 \times 10^{-2}$ & $2.62 \times 10^{-3}$ & $6.41 \times 10^{-3}$ & $4.55 \times 10^{-1}$ & $2.55 \times 10^{-2}$ & $3.66 \times 10^{-1}$ & $4.59 \times 10^{-2}$ & $3.24 \times 10^{-2}$ \\
\hline & FEC13-6 & 187.64 & 6.34 & $\mathrm{nd}^{\mathrm{c}}$ & $3.38 \times 10^{-2}$ & $3.52 \times 10^{-3}$ & $6.60 \times 10^{-3}$ & $6.18 \times 10^{-1}$ & $4.13 \times 10^{-2}$ & $5.46 \times 10^{-1}$ & $7.36 \times 10^{-2}$ & $4.27 \times 10^{-2}$ \\
\hline & FEC13-7 & 306.40 & $\mathrm{na}^{\mathrm{b}}$ & $\mathrm{nd}^{\mathrm{c}}$ & $4.21 \times 10^{-2}$ & $6.43 \times 10^{-3}$ & $6.32 \times 10^{-3}$ & $1.15 \times 10^{0}$ & $6.99 \times 10^{-2}$ & $9.93 \times 10^{-1}$ & $1.29 \times 10^{-1}$ & $5.85 \times 10^{-2}$ \\
\hline \multirow[t]{10}{*}{ Leg 4} & FEC14-1 & 306.40 & 8.076 & $1.95 \times 10^{-4}$ & $4.06 \times 10^{-2}$ & $1.88 \times 10^{-3}$ & $3.09 \times 10^{-4}$ & $1.12 \times 10^{0}$ & $7.89 \times 10^{-2}$ & $1.09 \times 10^{0}$ & $1.32 \times 10^{-1}$ & $5.80 \times 10^{-2}$ \\
\hline & FEC14-2 & 361.93 & 7.82 & $1.74 \times 10^{-4}$ & $4.27 \times 10^{-2}$ & $1.95 \times 10^{-3}$ & $1.98 \times 10^{-4}$ & $1.35 \times 10^{0}$ & $9.22 \times 10^{-2}$ & $1.28 \times 10^{0}$ & $1.54 \times 10^{-1}$ & $6.28 \times 10^{-2}$ \\
\hline & FEC14-3 & 409.63 & 7.476 & $1.67 \times 10^{-4}$ & $4.38 \times 10^{-2}$ & $2.10 \times 10^{-3}$ & $1.53 \times 10^{-4}$ & $1.52 \times 10^{0}$ & $1.05 \times 10^{-1}$ & $1.46 \times 10^{0}$ & $1.76 \times 10^{-1}$ & $6.67 \times 10^{-2}$ \\
\hline & FEC14-4 & 465.88 & 7.899 & $1.52 \times 10^{-4}$ & $4.51 \times 10^{-2}$ & $2.27 \times 10^{-3}$ & $1.25 \times 10^{-4}$ & $1.76 \times 10^{0}$ & $1.21 \times 10^{-1}$ & $1.68 \times 10^{0}$ & $2.00 \times 10^{-1}$ & $7.09 \times 10^{-2}$ \\
\hline & FEC14-5 & 632.48 & 7.772 & $1.39 \times 10^{-4}$ & $4.19 \times 10^{-2}$ & $2.81 \times 10^{-3}$ & $1.05 \times 10^{-4}$ & $2.37 \times 10^{0}$ & $1.62 \times 10^{-1}$ & $2.23 \times 10^{0}$ & $2.73 \times 10^{-1}$ & $7.24 \times 10^{-2}$ \\
\hline & FEC14-6 & 820.18 & 7.946 & $1.69 \times 10^{-4}$ & $3.89 \times 10^{-2}$ & $3.41 \times 10^{-3}$ & $8.62 \times 10^{-5}$ & $3.09 \times 10^{0}$ & $2.13 \times 10^{-1}$ & $2.90 \times 10^{0}$ & $3.51 \times 10^{-1}$ & $7.70 \times 10^{-2}$ \\
\hline & FEC14-7 & 1227.81 & 7.376 & $1.53 \times 10^{-4}$ & $2.82 \times 10^{-2}$ & $4.83 \times 10^{-3}$ & $6.16 \times 10^{-5}$ & $4.66 \times 10^{0}$ & $3.15 \times 10^{-1}$ & $4.40 \times 10^{0}$ & $5.26 \times 10^{-1}$ & $8.41 \times 10^{-2}$ \\
\hline & FEC14-8 & 1734.09 & 6.87 & $1.30 \times 10^{-4}$ & $1.94 \times 10^{-2}$ & $6.40 \times 10^{-3}$ & $4.65 \times 10^{-5}$ & $6.60 \times 10^{0}$ & $4.40 \times 10^{-1}$ & $6.20 \times 10^{0}$ & $7.44 \times 10^{-1}$ & $9.97 \times 10^{-2}$ \\
\hline & FEC14-9 & 2601.94 & 6.971 & $2.94 \times 10^{-4}$ & $1.23 \times 10^{-2}$ & $8.48 \times 10^{-3}$ & $3.12 \times 10^{-5}$ & $7.20 \times 10^{0}$ & $6.44 \times 10^{-1}$ & $6.61 \times 10^{0}$ & $1.09 \times 10^{0}$ & $1.28 \times 10^{-1}$ \\
\hline & FEC14-10 & 3389.64 & 7.322 & $2.66 \times 10^{-4}$ & $1.03 \times 10^{-2}$ & $9.02 \times 10^{-3}$ & $1.89 \times 10^{-5}$ & $7.42 \times 10^{0}$ & $8.09 \times 10^{-1}$ & $6.59 \times 10^{0}$ & $1.42 \times 10^{0}$ & $1.36 \times 10^{-1}$ \\
\hline
\end{tabular}

${ }^{\mathrm{a}}$ Measured at room temperature.

${ }^{\mathrm{b}}$ Not analyzed.

${ }^{\mathrm{c}}$ Not detected. Detection limits: $\mathrm{F}=0.25 \mathrm{ppm}, \mathrm{HCO}_{3}=1 \mathrm{ppm}$.

cium reflect an underprediction of solution $p \mathrm{H}$, although the $p \mathrm{H}$ in our models is below that which would affect amorphous silica. Unfortunately, in our study, $p \mathrm{H}$ is one of the most difficult parameters to predict because values at elevated temperature must be extrapolated to $25^{\circ} \mathrm{C}$ to compare with the measured values. The measured and predicted $p \mathrm{H}$ are then subject to change due to possible mineral precipitation and equilibration with atmospheric $\mathrm{CO}_{2}(\mathrm{~g})$ at room temperature. Furthermore, measured $p \mathrm{H}$ values in concen- trated solutions are uncorrected and do not represent real $\mathrm{H}^{+}$ activity. We have minimized the contribution of $p \mathrm{H}$ uncertainty to the observed discrepancy by constraining predicted $p \mathrm{H}$ by fitting the $\Sigma \mathrm{CO}_{2}(\mathrm{aq})$ concentration in leg 4 , where we observed measurable concentrations. This yields a solution in equilibrium with atmospheric $\mathrm{CO}_{2}$ and an initial $p \mathrm{H}$ of 7.5 at $95^{\circ} \mathrm{C}$. This is consistent with the experiment, because filtered laboratory air was continually passed over the solution as the waters evaporated, and because carbonate samples

TABLE IV. Results of x-ray diffraction analysis of precipitates formed from complete evaporation.

\begin{tabular}{lcccc}
\hline \hline & $\begin{array}{c}\text { Leg 1 } \\
\text { (Exp. FEC 9) }\end{array}$ & $\begin{array}{c}\text { Leg 2 } \\
\text { (Exp. FEC 12) }\end{array}$ & $\begin{array}{c}\text { Leg 3 } \\
\text { (Exp. FEC 13) }\end{array}$ & $\begin{array}{c}\text { Leg 4 } \\
\text { (Exp. FEC 14) }\end{array}$ \\
\hline Halite $(\mathrm{NaCl})$ & $\mathrm{X}$ & $\mathrm{X}$ & $\mathrm{X}$ & $\mathrm{X}$ \\
Anhydrite $\left(\mathrm{CaSO}_{4}\right)$ & $\mathrm{X}$ & $\mathrm{X}$ & $\mathrm{X}$ & $\mathrm{X}$ \\
Bassanite $\left(2 \mathrm{CaSO}_{4} \cdot \mathrm{H}_{2} \mathrm{O}\right)$ & & $\mathrm{X}$ & $\mathrm{X}$ \\
Niter $\left(\mathrm{KNO}_{3}\right)$ & & & $\mathrm{X}$ \\
Nitratine $\left(\mathrm{NaNO}_{3}\right)$ & & & $\mathrm{X}$ \\
\hline \hline
\end{tabular}


were stored in gas-tight vials eliminating exchange with atmospheric $\mathrm{CO}_{2}$ at room temperature. We also assume that the undiluted, sealed samples taken for $p \mathrm{H}$ measurement did not re-equilibrate with atmospheric $\mathrm{CO}_{2}$ as they cooled from $95^{\circ} \mathrm{C}$ to room temperature. The good agreement between measured and predicted $p \mathrm{H}$ at lower ionic strengths in legs 1 and 2 supports these modeling constraints.

\section{DISCUSSION}

\section{A. Chemical divides}

The important chemical divides that control the composition of brines formed from dilute sulfate type waters are halite, bassanite (or other calcium sulfates), magnesium silicate, amorphous silica, and possibly fluorite and brucite based on experimental results and model predictions. The early removal of fluoride from the starting solution is an important geochemical control for eliminating the evolution of a potentially corrosive fluoride containing brine. The precipitation of calcium as a calcium carbonate is not a major chemical divide for this solution. At $95^{\circ} \mathrm{C}$ and atmospheric $\mathrm{CO}_{2}(\mathrm{~g})$, carbonate is partitioned into the gas phase rather than the precipitation of calcium carbonate. The solution is below calcite solubility for most of the experiment. The precipitation of calcium as bassanite and magnesium as a magnesium silicate are important geochemical controls that limit the calcium and magnesium content in these brines. Additionally, the very low fluoride solubility limits chloride to be the most corrosive agent of Yucca Mountain sulfate type pore waters. High nitrate to chloride ratios of brines are known to limit susceptibility to localized corrosion of corrosion resistant materials such as the candidate waste package material. ${ }^{18,19}$ The brine contained a nitrate to chloride ratio of 0.2:1 at $99.97 \%$ evaporation. This ratio will increase with increasing evaporation because the chloride will be controlled by halite solubility, and nitrate will continue to concentrate until the solution reaches saturation with respect to nitratine $\left(\mathrm{NaNO}_{3}\right)$ and/or niter $\left(\mathrm{KNO}_{3}\right)$.

Although the $\mathrm{Ca}: \mathrm{SO}_{4}: \mathrm{HCO}_{3}$ ternary diagrams do not capture all of the important chemical divides that affect the composition of Yucca Mountain pore waters, they can be used to categorize the types of brines that will form from the wide range of Yucca Mountain pore waters. Evaporation of dilute sulfate (this study), bicarbonate and calcium chloride ${ }^{5}$ type Yucca Mountain waters evolve toward their respective sulfate, carbonate, and calcium chloride brines indicated by their initial $\mathrm{Ca}: \mathrm{SO}_{4}: \mathrm{HCO}_{3}$ ratios (Fig. 2).

\section{B. High temperature Pitzer model}

The comparison of experimental results and model predictions of the evaporation of synthetic Topopah Spring Tuff pore water at $95^{\circ} \mathrm{C}$ indicates that the current hightemperature Pitzer database used by the Yucca Mountain program adequately describes the chemical evolution of brines at elevated temperature for most species (Fig. 3). In this section we discuss our results in light of the high temperature Pitzer ion interaction database that includes solubility products for solids. Table II lists temperature-dependent Pitzer interaction parameters for binary and ternary reactions and Table V details the solubility products relevant to this work.

The Yucca Mountain Project high temperature Pitzer ion interaction database is the most comprehensive database available to account for the nonideal behavior of highly concentrated electrolytes over a wide range of temperature $\left(0-140{ }^{\circ} \mathrm{C}\right)$. The database was founded on the original variable-temperature Pitzer parameters ${ }^{20,21}$ supplemented by parameter data from several other sources. ${ }^{13,22-32}$ It also includes thermodynamic parameters converted from nonstandard Pitzer equations from the published literature. ${ }^{14}$ Temperature-independent parameters based on $25^{\circ} \mathrm{C}$ data are used for several parameters where temperature dependent data are lacking. ${ }^{13}$ The database contains temperaturedependent ion interaction parameters for most ion groups relevant to our experimental system at $95{ }^{\circ} \mathrm{C}$. Exceptions include $25^{\circ} \mathrm{C}$ models for potassium nitrate interactions and some calcium and magnesium ion interactions; ${ }^{13}$ and 20-90 ${ }^{\circ} \mathrm{C}$ models for $\mathrm{CO}_{2}(\mathrm{aq})$ ion interactions. ${ }^{26}$ Substantial database and model validation has been performed, ${ }^{1}$ however, it is acknowledged that the results of any model are only as good as the input parameters and database used, and typically, improvements will always be made to bridge the gaps between experimental observations and model predictions.

\section{1. $\mathrm{Na}^{+}, \mathrm{Cl}^{-}, \mathrm{K}^{+}$, and $\mathrm{NO}_{3}^{-}$}

The excellent agreement between model prediction and experiment for sodium, chloride, potassium, and nitrate suggests that the high temperature Pitzer ion interaction database and halite solubility product adequately describes the nonideal solution chemistry at high ionic strength and elevated temperature for these elements, as well as the halite solubility product. The agreement is expected for sodium and chloride because interaction parameters for binary and ternary ion groups are well defined as a function of temperature. ${ }^{14,21,25,27,33-35}$

The excellent agreement between prediction and experiment for potassium and nitrate suggests that Pitzer parameters for the $\mathrm{K}^{+}-\mathrm{NO}_{3}^{-}$ion interaction will yield accurate predictions of pore water concentrations in evaporating solutions despite being measured at $25^{\circ} \mathrm{C}$ and applied to $95^{\circ} \mathrm{C}$ systems. The reason for this is that high sodium to potassium, and chloride to nitrate mole ratios seen in our experiments may effectively mask any mismatch due to constant $25^{\circ} \mathrm{C}$ parameters. Clearly, this is true for undersaturated brines with respect to $\mathrm{KNO}_{3}$ (niter) because $\mathrm{Na}^{+}-\mathrm{NO}_{3}^{-}$ and $\mathrm{K}^{+}-\mathrm{Cl}^{-}$interactions will be more important than $\mathrm{K}^{+}-\mathrm{NO}_{3}^{-}$interactions in determining solution properties. However, when brines are saturated with niter $\left(\mathrm{KNO}_{3}\right)$, then $\mathrm{K}^{+}-\mathrm{NO}_{3}^{-}$interactions are more important. The extent that the constant temperature $\mathrm{K}^{+}-\mathrm{NO}_{3}^{-}$interaction parameter does not accurately predict behavior was shown in $\mathrm{KNO}_{3}-\mathrm{NaNO}_{3}$ deliquescence experiments at $90{ }^{\circ} \mathrm{C}$. In solutions saturated with respect to niter/nitratine, they showed an underprediction of niter solubility by as much as $50 \%{ }^{35}$ 
TABLE V. Log $K$ temperature grid.

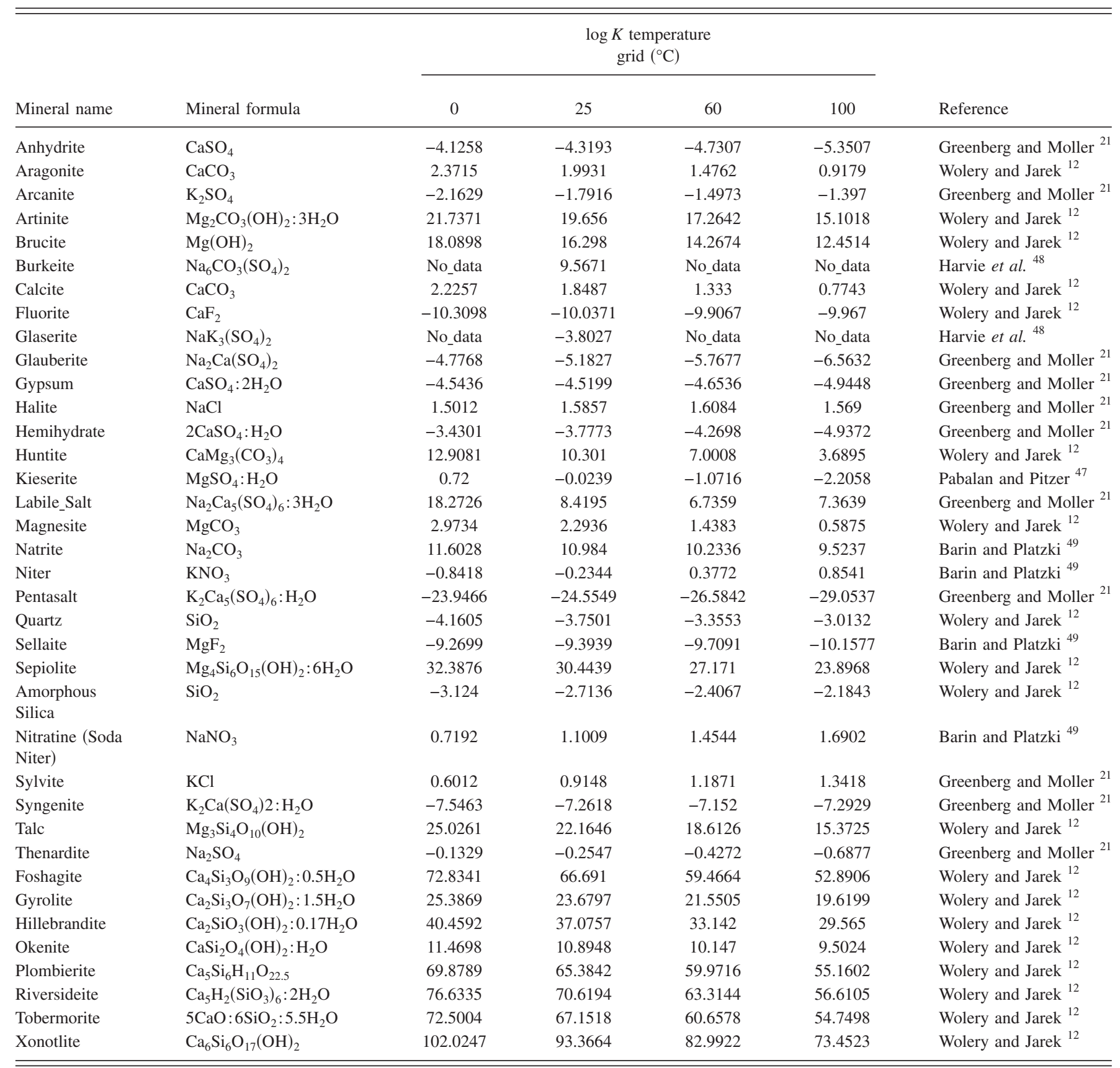

\section{2. $\mathrm{Ca}^{2+}$ and $\mathrm{SO}_{4}^{2-}$}

The discrepancy between experimental results and model prediction for dissolved calcium and sulfate concentrations observed in the high ionic strength solutions of leg 4 may be due to either the temperature-dependent $\mathrm{Ca}^{2+}-\mathrm{SO}_{4}^{2-}$ Pitzer parameters or an uncertainty in the physical nature of the calcium sulfate precipitate formed during the course of the experiment. The parameters in the Yucca Mountain database are derived from a refit of the Moller, ${ }^{20}$ and Greenberg and Moller ${ }^{21}$ models, but without an explicit temperature dependent $\mathrm{CaSO}_{4}(\mathrm{aq})$ ion pair. To examine the ability of the high temperature Pitzer parameters to accurately predict calcium sulfate solubility, we compare model calculations to literature anhydrite and bassanite solubility in solutions of varying sodium chloride concentrations. ${ }^{36,37}$ The results are presented in Fig. 5 and show agreement within 0.01 molal between predicted and measured anhydrite and bassanite solubility, which is similar to the agreement between measured and predicted calcium in our evaporation experiment, but it is as much as seven times lower than the measured and predicted sulfate in our evaporation experiments.

The exact nature of the calcium sulfate solid phase formed in the experiment and controlling the solution concentrations of both calcium and sulfate may also contribute to the discrepancy between evaporation models and experiment. Gypsum changes rapidly to bassanite in contact with water at $97.5^{\circ} \mathrm{C}^{38}$ while bassanite is considered metastable and in turn is converted slowly to anhydrite at similar temperatures. ${ }^{39}$ The gypsum-anhydrite transition temperature of $42{ }^{\circ} \mathrm{C}$ is known to increase in the presence of addi- 

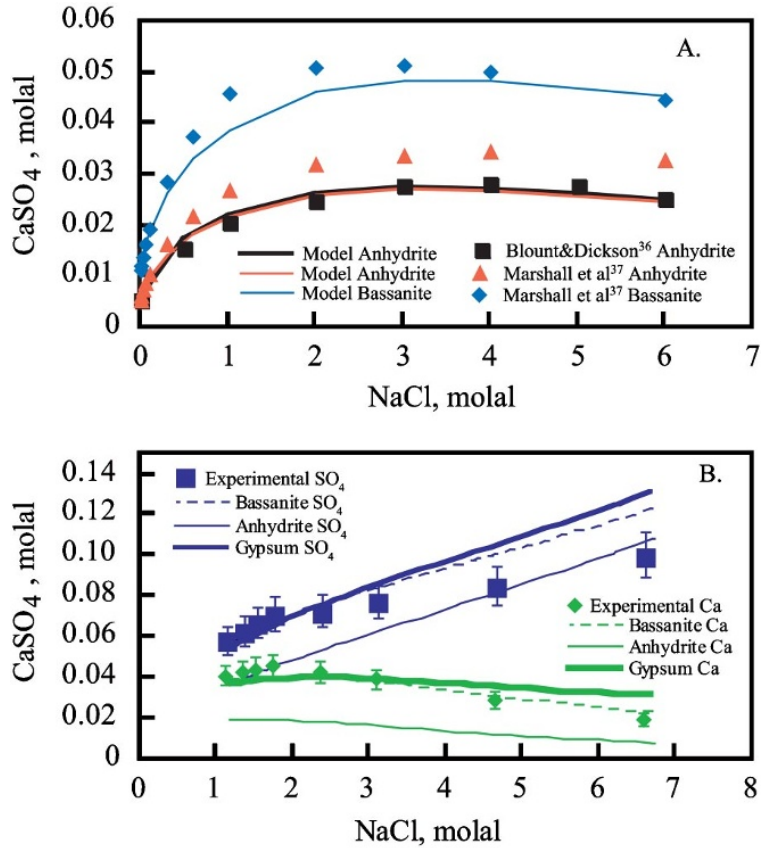

FIG. 5. (Color) (a) Comparison of literature and calculated anhydrite and bassanite solubility data. Literature values were only obtained up to 6 molal sodium, therefore our calcium sulfate validation is limited to this upper value. (b) Comparison of modeled calcium and sulfate concentrations using bassanite, anhydrite, and gypsum as the solubility controlling mineral phase and leg 4 calcium and sulfate concentrations prior to modeled halite formation.

tional salts in solution. Recall that both bassanite and anhydrite were identified by XRD at the end of the experimental evaporation. Clearly, our experimental conditions are such that gypsum-bassanite-anhydrite transitions may occur both during the evaporation experiment at $95{ }^{\circ} \mathrm{C}$ and during the drying of the final precipitates at $40{ }^{\circ} \mathrm{C}$ prior to XRD analysis. Our experimental calcium concentrations during the evaporation in leg 4 generally fall between those predicted by the presence of bassanite and anhydrite [Fig. 5(b)]. The $\mathrm{CaSO}_{4}$ solubility comparison shown in Fig. 5(a) is validated only to 6 molal, prior to the precipitation of halite. A theoretical solid solution composition with end members resembling both bassanite and anhydrite may be more appropriate in describing the nature of our evaporation solids.

\section{3. $\Sigma \mathrm{CO}_{2}(\mathrm{aq})$ and $\mathrm{pH}$}

The prediction of solution $p \mathrm{H}$ is important because $p \mathrm{H}$ greatly affects the solubility of many carbonate and silicate phases. The Pitzer database contains parameters for several ion interactions that were derived from highly acidic or alkaline solutions ( 0 to $>6$ molal) that are not representative of the $p \mathrm{H}$ of natural solutions or brines $(4<p \mathrm{H}<12)$. In natural systems, the $p \mathrm{H}$ is strongly tied to the partial pressure of $\mathrm{CO}_{2}(\mathrm{~g})$, as well as the dissociation of $\mathrm{CO}_{2}(\mathrm{aq})$ to $\mathrm{HCO}_{3}^{-}$ and $\mathrm{CO}_{3}^{2-}$. He and $\mathrm{Morse}^{26}$ derived Pitzer parameters for ion interactions involving $\mathrm{CO}_{2}(\mathrm{aq}), \mathrm{HCO}_{3}^{-}$and $\mathrm{CO}_{3}^{2-}$ in strong electrolytes containing sodium, potassium, calcium, magnesium, chloride, and sulfate from calcite solubility experiments from 0 to $90{ }^{\circ} \mathrm{C}$. While the parameters based on $\mathrm{He}$

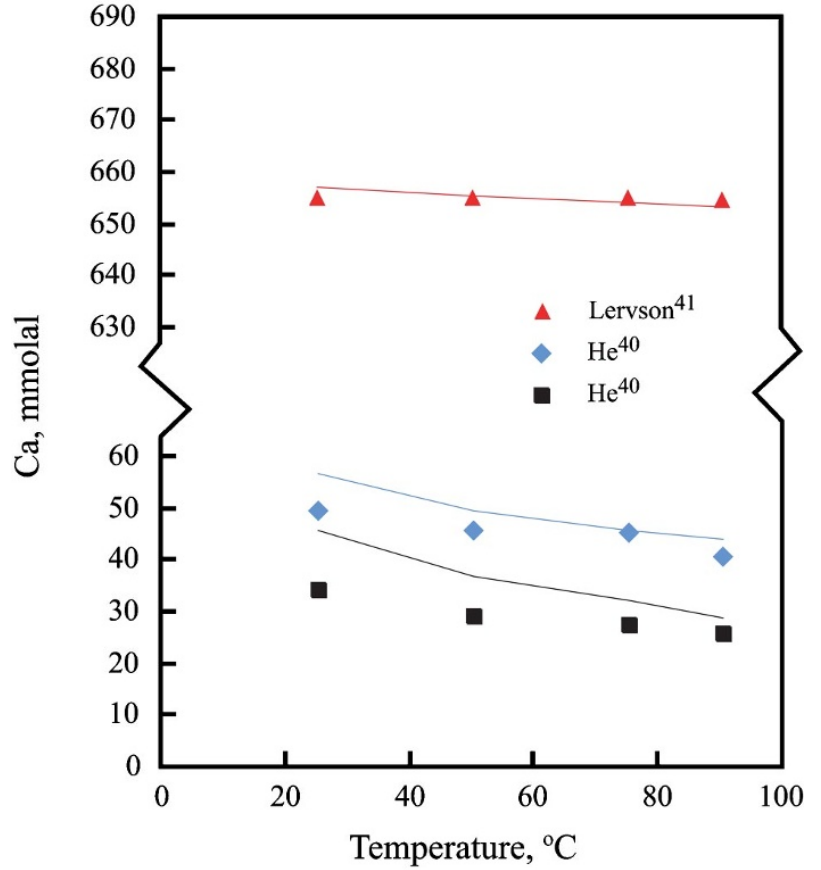

FIG. 6. (Color) Comparison of model data to literature calcite solubility data approached from undersaturation in synthetic brines (Ref. 26). Lines represent LLNL model and symbols represent (Ref. 40) and Lervson (Ref. 41) experimental data.

and Morse ${ }^{26}$ are incorporated into the Yucca Mountain Pitzer database, the Pitzer parameter temperature function embedded in the EQ3/6 code is not always consistent with published Pitzer data (e.g., too few or too many Pitzer parameters). Consequently, Pitzer data are required to be refit to be internally consistent with both the EQ3/6 code. As stated earlier, we measured only uncorrected $p \mathrm{H}$ values in our evaporation study and most measured carbonate concentrations fell below the analytical limit of detection.

To evaluate our ability to model $\mathrm{H}_{2} \mathrm{O}-\mathrm{CO}_{2}$ systems, we utilized the equilibria between calcite, dissolved carbonate, and $p \mathrm{H}$. We compare model calculations with known literature calcite solubility data approached from undersaturation in 1 to 5 molal sodium chloride brines (with lesser concentrations of potassium, calcium, and sulfate) from 25 to $90{ }^{\circ} \mathrm{C} .{ }^{40,41}$ We do not compare similar calcite seeded experiments approached from supersaturation because $\mathrm{He}$ and Morse ${ }^{26}$ observed higher solubility, which they attributed to cation substitution in the precipitated calcite. The results are shown in Fig. 6. At higher temperatures approaching those of our evaporation study, model calculations match calcite solubility to within $0.003-0.004$ molal. Thus model calculations of $p \mathrm{H}$ and $\Sigma \mathrm{CO}_{2}(\mathrm{aq})$ are reasonable reflections of the experimental equilibrium.

\section{4. $\mathrm{Mg}$ and $\mathrm{Si}$}

The factor of 2 discrepancy between model and experiment for magnesium and silica solubility translates to absolute concentrations on the order of 0.01 molal for magnesium and only $10^{-5}$ molal for silica. This agreement suggests that the use of sepiolite and brucite $\left(\mathrm{Mg}(\mathrm{OH})_{2}\right)$ to model magnesium and silica solubility, and the high temperature Pitzer 


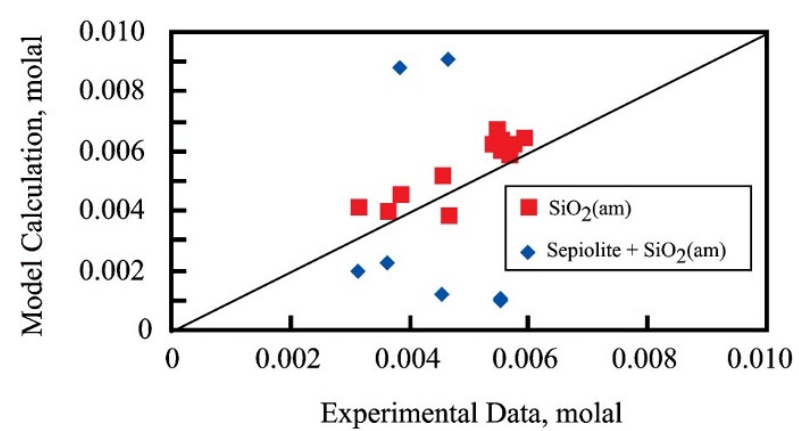

FIG. 7. (Color) Comparison of silica solubility data in $\mathrm{MgCl}_{2}$ and $\mathrm{NaCl}$ electrolytes at $100{ }^{\circ} \mathrm{C}$ (Ref. 46) with predicted model calculations using the high temperature Pitzer ion interaction data base. Note that the smaller number of data plotted in the calculations, where both sepiolite and amorphous silica are allowed to control solubility, reflects the $\mathrm{MgCl}_{2}$ electrolytes only.

parameters are adequate for the evaporation of waters in a repository environment. Since precipitates formed in the synthesis of the initial solution were not carried over to evaporation studies, formation (and loss through precipitation) of magnesium and silica solids could result in a discrepancy between model and experimental results. Uncertainty in the sepiolite solubility product is well defined at temperatures less than $100{ }^{\circ} \mathrm{C}$, with $\log K_{\mathrm{sp}}=24 \quad( \pm 0.3)$ at $95^{\circ} \mathrm{C}$ $\left(\mathrm{Mg}_{4} \mathrm{Si}_{6} \mathrm{O}_{15}(\mathrm{OH})_{2} \cdot 4 \mathrm{H}_{2} \mathrm{O}+8 \mathrm{H}^{+}=4 \mathrm{Mg}^{2+}+6 \mathrm{SiO}_{2}(\mathrm{aq})\right.$

$\left.+11 \mathrm{H}_{2} \mathrm{O}\right){ }^{42}$ This translates to less than $10 \%$ uncertainty. Sepiolite has been observed as a likely control for the removal of magnesium and/or silica in other systems such as at Saline Valley, CA that have a brine evolution similar to this experimental pore water. ${ }^{43}$ It is doubtful that an amorphous magnesium silicate forms, because the model slightly overpredicts magnesium and silica concentrations. The observed match between model and experiment also suggests that the suppression of talc is valid because its formation is thought to be kinetically unfavorable. However, additional studies are needed to identify the magnesium silicate phase that controls solubility.

The absolute overprediction of silica solubility is well within the uncertainty of Pitzer parameters in the high temperature database. We evaluate the $\mathrm{Mg}^{2+}-\mathrm{SiO}_{2}(\mathrm{aq})$ Pitzer parameters by comparing model calculations of $\mathrm{SiO}_{2}(\mathrm{am})$ solubility data in magnesium and sodium containing electrolytes at $100{ }^{\circ} \mathrm{C}$ in Fig. 7. ${ }^{44,45} \mathrm{Mg}^{2+}-\mathrm{SiO}_{2}$ (aq) Pitzer parameters were initially derived from amorphous silica solubility measured in a range of electrolyte solutions ${ }^{32,44-46}$ in which parameter accuracy is limited by low silica concentrations and uncertainty in the chemical potential for amorphous silica. $^{32}$ Model calculations in systems in which amorphous silica controls solubility (sepiolite is suppressed) slightly overpredict silica solubility by 0.001 molal on average. If sepiolite and amorphous silica are allowed to control silica solubility, then the scatter in the data noticeably increases to an average of 0.003 molal. These values are more than two orders of magnitude higher than the overprediction observed in our evaporation study.

\section{CONCLUSION}

The assessment of water chemistry that may contact the waste containers and drip shields at the Yucca Mountain high-level radioactive waste repository in Nevada requires the calculation of a wide range of water composition over 10000 year time periods in an environment in which temperature and relative humidity will change as the repository heats up and cools down. Understanding and verifying the chemical divides that control brine composition as seepage water evaporates is important to placing boundaries on the corrosiveness of the chemical environment to waste package materials. The model data generated for this solution by EQ3/ 6 geochemical code and high temperature Pitzer database indicate that they can provide satisfactory predictions as compared to the experimental data in most cases. The water evolved toward a complex sulfate type brine that contained about $45 \mathrm{~mol} \% \mathrm{Na}, 40 \mathrm{~mol} \% \mathrm{Cl}, 9 \mathrm{~mol} \% \mathrm{NO}_{3}, 5 \mathrm{~mol} \%$ $\mathrm{K}$, and less than $1 \mathrm{~mol} \%$ each of $\mathrm{SO}_{4}, \mathrm{Ca}, \mathrm{Mg}, \Sigma \mathrm{CO}_{2}(\mathrm{aq}), \mathrm{F}$, and $\mathrm{Si}$ at a concentration factor of about $3500 \times$. Minerals predicted to form include halite, anhydrite, bassanite, niter, and nitratine in addition to fluoride, carbonate, sulfate, and magnesium silicate precipitates. This work is of importance to the continued validation of the Pitzer ion-interaction parameter database and geochemical modeling used by the Yucca Mountain Project, and supports its adequate capabilities in predicting brine evolution in complex aqueous systems at elevated temperatures.

\section{ACKNOWLEDGMENTS}

The authors would like to thank Brian Viani and Tom Wolery at LLNL for their guidance and discussion regarding $\mathrm{x}$-ray diffraction data and thermodynamic modeling, respectively, and Kirk Staggs for his invaluable skills in making these experiments possible. This work was performed under the auspices of the U.S. Department of Energy by the University of California Lawrence Livermore National Laboratory under Contract No. W-7405-Eng-48.

${ }^{1}$ Bechtel SAIC Company, In-Drift Precipitates/Salts Model, Analysis Model Report No. ANL-EBS-MD-000045 Rev 01 ICN 01 (2004) Available at www.ocrwm.doe.gov/technical/amr.shtml. Accessed March 2005.

${ }^{2}$ H. P. Eugster and L. A. Hardie, in Lakes: Chemistry, Geology, Physics, edited by A. Lerman (Springer, New York, 1978).

${ }^{3}$ J. I. Drever, The Geochemistry of Natural Waters: Surface and Groundwater Environments, 3rd ed. (Prentice-Hall, Englewood Cliffs, NJ, 1997).

${ }^{4}$ E. L. Eary, J. Geochemical Exploration 64, 223 (1998).

${ }^{5}$ N. D. Rosenberg, G. E. Gdowski, and K. G. Knauss, Appl. Geochem. 16, 1231 (2001).

${ }^{6}$ I. C. Yang, G. W. Rattray, and P. Yu, USGS Water Resources Investigation Report No. 96-4058, US Geological Survey, Denver, CO 1996.

Z7. E. Peterman and B. D. Marshall, Geological Society of America Abstracts with Programs 34, 308 (2002).

${ }^{8}$ Bechtel SAIC Company, FY01 Supplemental Science and Performance Analysis, V. 1 Scientific Basis and Analyses, Report No. TDR-MGR-MD000007 REV 0, p. 6-56 to 6-59 (2001). Available at http://lsnnet.gov. Accessed March 2005.

${ }^{9}$ L. A. Hardie and H. P. Eugster, Mineral Soc. Am. Spec. Pap. 3, 273 (1970).

${ }^{10} \mathrm{~J}$. Li, T. K. Lowenstein, and I. R. Blackburn, Geol. Soc. Am. Bull. 109, 1361 (1997)

${ }^{11}$ R. G. Bates, Pure Appl. Chem. 36, 407 (1973).

${ }^{12}$ Bechtel SAIC Company, EQ3/6, A software package for geochemical modeling of aqueous systems, v8.0, 2003, developed by T. J. Wolery and R. L. Jarek, and available from Bechtel SAIC STN: 10813-8.0-00.

${ }^{13}$ K. S. Pitzer, Activity Coefficients in Electrolyte Solutions, 2nd ed. (CRC Press, Boca Raton, FL, 1991).

${ }^{14}$ J. A. Rard and A. M. Wijesinghe, J. Chem. Thermodyn. 35, 439 (2003).

${ }^{15}$ A. L. Pulvirenti, K. M. Needham, M. A. Adel-Hadadi, E. J. Bishop, A. 
Barkatt, C. R. Marks, and J. A. Gorman, Mater. Res. Soc. Symp. Proc. 757, 587 (2003).

${ }^{16}$ D. B. Kent and M. Kastner, Geochim. Cosmochim. Acta 49, 1123 (1985).

${ }^{17}$ D. Rai, A. R. Felmy, S. P. Juracich, and F. Rao, SAND94-1949 UC-721, Sandia National Laboratories, Albuquerque, NM, 1995.

${ }^{18}$ D. S. Dunn and C. S. Brossia, Corrosion Paper No. 02548, 2002.

${ }^{19}$ G. M. Gordon, Corrosion (Houston) 58, 811 (2002).

${ }^{20}$ N. Moller, Geochim. Cosmochim. Acta 52, 821 (1988).

${ }^{21}$ J. P. Greenberg and N. Moller, Geochim. Cosmochim. Acta 53, 2503 (1989).

${ }^{22}$ H. F. Holmes and R. E. Mesmer, J. Phys. Chem. 87, 1242 (1983).

${ }^{23}$ H. F. Holmes and R. E. Mesmer, J. Chem. Thermodyn. 30, 723 (1998).

${ }^{24}$ H. F. Holmes and R. E. Mesmer, J. Chem. Thermodyn. 26, 581 (1994).

${ }^{25}$ R. T. Pabalan and K. S. Pitzer, Geochim. Cosmochim. Acta 51, 2429 (1987).

${ }^{26}$ S. He and J. W. Morse, Geochim. Cosmochim. Acta 57, 3533 (1993).

${ }^{27}$ H. F. Holmes, R. H. Busey, J. M. Simonson, and R. E. Mesmer, J. Chem. Thermodyn. 19, 863 (1987).

${ }^{28}$ C. S. Oakes and A. R. Felmy, J. Chem. Thermodyn. 32, 29 (2000).

${ }^{29}$ S. L. Clegg, S. Milioto, and D. A. Palmer, J. Chem. Eng. Data 41, 455 (1996).

${ }^{30}$ W. E. Thiessen and J. M. Simonson, J. Phys. Chem. 94, 7794 (1990).

${ }^{31}$ S. L. Clegg and P. Brimblecombe, Geochim. Cosmochim. Acta 54, 3315 (1990).

${ }^{32}$ A. R. Felmy, C. C. Schroeder, and M. J. Mason, presented at the Symposium of Scientific Issues Related to Safety and Treatment of Hanford Waste Tanks, Washington, DC, 21-26 August 1994, PNL-SA-25345, (1994).

${ }^{33}$ D. G. Archer, J. Phys. Chem. Ref. Data 29, 1141 (2000).
${ }^{34}$ S. M. Sterner, A. R. Felmy, C. S. Oakes, and K. S. Pitzer, Int. J. Thermophys. 19, 761 (1998).

${ }^{35}$ L. Craig, S. Carroll, and T. Wolery, Water Rock Interaction Proceedings WRI-11, 2004, Vol. II, p. 1275.

${ }^{36}$ C. W. Blount and F. W. Dickson, Geochim. Cosmochim. Acta 33, 227 (1969).

${ }^{37}$ W. L. Marshall, R. Slusher, and E. V. Jones, J. Chem. Eng. Data 9, 187 (1964).

${ }^{38}$ E. Posnjak, Am. J. Sci. 235, 247 (1938).

${ }^{39}$ E. Partridge and A. H. White, J. Am. Chem. Soc. 51, 201 (1929).

${ }^{40} \mathrm{~S}$. He, Ph.D. dissertation, Texas A\&M University, 1992.

${ }^{41}$ A. I. Lervson, Geology of Petroleum, 2nd ed. (Freeman, San Francisco, (1967).

${ }^{42}$ H. C. Helgeson, J. M. Delany, H. W. Nesbitt, and D. K. Bird, Am. J. Sci. 278, 129 (1978).

${ }^{43}$ L. A. Hardie, Geochim. Cosmochim. Acta 22, 1279 (1968).

${ }^{44}$ W. L. Marshall and C. A. Chen, Geochim. Cosmochim. Acta 46, 289 (1982).

${ }^{45}$ W. L. Marshall and C. A. Chen, Geochim. Cosmochim. Acta 46, 367 (1982).

${ }^{46}$ C. A. Chen and W. L. Marshall, Geochim. Cosmochim. Acta 46, 279 (1982).

${ }^{47}$ R. T. Pabalan and K. S. Pitzer, Geochim. Cosmochim. Acta 51, 829 (1987).

${ }^{48}$ C. E. Harvie, N. Moller, and J. H. Weare, Geochim. Cosmochim. Acta 48, 723 (1984).

${ }^{49}$ I. Barin and G. Platzki, Thermochemical Data of Pure Substances, 3rd ed. (VCH, 1995). 